\title{
Voltage-Gated $\mathrm{K}^{+}$Channel $\beta$ Subunits: Expression and Distribution of $\mathrm{Kv} \beta 1$ and $\mathrm{Kv} \beta 2$ in Adult Rat Brain
}

\author{
Kenneth J. Rhodes, ${ }^{1}$ Michael M. Monaghan, ${ }^{1}$ Nestor X. Barrezueta, ${ }^{1}$ Stanley Nawoschik, ${ }^{1}$ \\ Zewditu Bekele-Arcuri, ${ }^{2}$ Maria F. Matos, ${ }^{2}$ Kensuke Nakahira, ${ }^{2}$ Lee E. Schechter, ${ }^{1}$ and James S. Trimmer ${ }^{2}$ \\ ${ }^{1}$ CNS Disorders, Wyeth-Ayerst Research, Princeton, New Jersey 08543, and 2Department of Biochemistry and Cell \\ Biology and Institute for Cell and Developmental Biology, State University of New York, Stony Brook, New York 11794
}

\begin{abstract}
Recent cloning of $\mathrm{K}^{+}$channel $\beta$ subunits revealed that these cytoplasmic polypeptides can dramatically alter the kinetics of current inactivation and promote efficient glycosylation and surface expression of the channel-forming $\alpha$ subunits. Here, we examined the expression, distribution, and association of two of these $\beta$ subunits, $\operatorname{Kv} \beta 1$ and $\operatorname{Kv} \beta 2$, in adult rat brain. In situ hybridization using cRNA probes revealed that these $\beta$-subunit genes are heterogeneously expressed, with high densities of $\mathrm{Kv} \beta 1 \mathrm{mRNA}$ in the striatum, CA1 subfield of the hippocampus, and cerebellar Purkinje cells, and high densities of $\mathrm{Kv} \beta 2$ mRNA in the cerebral cortex, cerebellum, and brainstem. Immunohistochemical staining using subunit-specific monoclonal and affinity-purified polyclonal antibodies revealed that the $\mathrm{Kv} \beta 1$
\end{abstract}

and $\mathrm{Kv} \beta 2$ polypeptides frequently co-localize and are concentrated in neuronal perikarya, dendrites, and terminal fields, and in the juxtaparanodal region of myelinated axons. Immunoblot and reciprocal co-immunoprecipitation analyses indicated that $\mathrm{Kv} \beta 2$ is the major $\beta$ subunit present in rat brain membranes, and that most $\mathrm{K}^{+}$channel complexes containing $\mathrm{Kv} \beta 1$ also contain $\mathrm{Kv} \beta 2$. Taken together, these data suggest that $\mathrm{Kv} \beta 2$ is a component of almost all $\mathrm{K}^{+}$channel complexes containing Kv1 $\alpha$ subunits, and that individual channels may contain two or more biochemically and functionally distinct $\beta$-subunit polypeptides.

Key words: ion channel; central nervous system; auxiliary subunit; striatum; immunoprecipitation; immunohistochemistry
Voltage-gated $\mathrm{K}^{+}$channels are composed of pore-forming $\alpha$ subunits and associated cytoplasmic $\beta$-subunit polypeptides (Pongs, 1995). These channels are critical for action potential conduction and neurotransmitter release, and are essential to the control of neuronal excitability (Hille, 1992). Expression of $\alpha$-subunit mRNAs in heterologous cells gives rise to tetrameric channel complexes with electrophysiological characteristics similar to A-type or delayed-rectifier channels (for review, see Pongs, 1992). The large number of $\alpha$-subunit genes, their ability to assemble into heteromultimers (Ruppersberg et al., 1990; Sheng et al., 1993; Wang et al., 1993; Scott et al., 1994a; Rhodes et al., 1995), and their heterogeneous expression in mammalian brain undoubtedly contributes to the diversity of voltage-gated $\mathrm{K}^{+}$ channels in situ (Stühmer et al., 1989; Jan and Jan, 1990). However, the recent discovery of auxiliary subunits associated with ion channels in general (for review, see Isom et al., 1994), and with voltage-gated $\mathrm{K}^{+}$channels in particular (Parcej et al., 1992; Rettig et al., 1994; Scott et al., 1994b), revealed that their electrophysiological and biochemical properties can be dramatically affected by the presence of $\beta$ subunits (Rettig et al., 1994; Majumder et al., 1995; Morales et al., 1995; Shi et al., 1996). This association of $\beta$ subunits with $\mathrm{K}^{+}$channels not only increases the potential for diversity, it also indicates that the functional properties of indi-

\footnotetext{
Received Jan. 18, 1996; revised May 9, 1996; accepted May 21, 1996.

This work was supported by Wyeth-Ayerst Research and the Center for Biotechnology at Stony Brook, and funded by the New York State Science and Technology Foundation and by National Institutes of Health Grant NS34383 (J.S.T.). This work was done during the tenure of an Established Investigatorship from the American Heart Association (J.S.T.). We thank Drs. James E. Barrett and John A. Moyer for critically reviewing this manuscript.

Correspondence should be addressed to Dr. James S. Trimmer, Department of Biochemistry and Cell Biology, State University of New York, Stony Brook, NY 11794-5215.

Copyright (C) 1996 Society for Neuroscience $0270-6474 / 96 / 164846-15 \$ 05.00 / 0$
}

vidual channels are governed by the specific combination of $\alpha$ and $\beta$ subunits present in the channel complex.

The $\beta$ subunits of voltage-gated $\mathrm{K}^{+}$channels were identified as $38-41 \mathrm{kDa}$ polypeptides associated with the dendrotoxin acceptor purified from bovine brain (Parcej and Dolly, 1989, 1992; Scott et al., 1994a,b), and as a $38 \mathrm{kDa}$ polypeptide in immunoprecipitated rat brain $\mathrm{K}^{+}$channel complexes (Trimmer, 1991). Subsequent cloning of cDNAs encoding a bovine $\beta$ subunit (Scott et al., $1994 b$ ); the related $\operatorname{Kv} \beta 1, \operatorname{Kv} \beta 2$, and $\operatorname{Kv} \beta 3$ in rat brain (Rettig et al., 1994; Heinemann et al., 1995); and closely related $\beta$ subunits in Drosophila (Chouinard et al., 1995), ferret (Morales et al., 1995), and human tissues (England et al., 1995a,b; Majumder et al., 1995; McCormack et al., 1995) indicated that these $\beta$ subunits are highly conserved and that some can modulate the rate of inactivation of certain $\alpha$ subunits (Rettig et al., 1994; England et al., 1995a,b; Heinemann et al., 1995; Majumder et al., 1995; McCormack et al., 1995; Morales et al., 1995).

We recently reported that $\operatorname{Kv} \beta 1$ and $\operatorname{Kv} \beta 2$ associate with $\alpha$ subunits early in their biosynthesis and exert chaperone-like effects on the $\alpha$ subunits, promoting their efficient glycosylation and stable expression in the plasma membrane (Shi et al., 1996). In addition, we reported that $\operatorname{Kv} \beta 1$ and $\operatorname{Kv} \beta 2$ associate with all members of the Shaker-related (Kv1) $\alpha$-subunit subfamily upon co-expression in transfected mammalian cells (Nakahira et al., 1996). Here, we used riboprobes and antibodies specific for $\mathrm{Kv} \beta 1$ and $\operatorname{Kv} \beta 2$ to examine their expression, subcellular distribution, and co-association in adult rat brain. We observed that these $\beta$ subunits are widely expressed, and that immunoreactivity for $\mathrm{Kv} \beta 1$ and $\mathrm{Kv} \beta 2$ is concentrated in multiple subcellular domains including neuronal somata and dendrites, the paranodal segments of myelinated axons, and in the terminal fields of several cortical and subcortical projection systems. We also observed that $\mathrm{Kv} \beta 2$ is 
the predominant $\beta$-subunit isoform in rat brain; although $\mathrm{Kv} \beta 1$ mRNA is widely expressed, the $\mathrm{Kv} \beta 1$ polypeptide is not a major component of the total rat brain $\beta$-subunit pool, and almost all of the $\mathrm{Kv} \beta 1$ that is present is in $\mathrm{K}^{+}$channel complexes that also contain $\operatorname{Kv} \beta 2$. Together, these observations suggest that $\beta$ subunits are integral components of $\mathrm{K}^{+}$channel complexes, and that the inclusion of $\mathrm{Kv} \beta 1$ in $\mathrm{Kv} \beta 2$-containing complexes may serve to fine tune the electrophysiological properties of channels in specific brain regions.

\section{MATERIALS AND METHODS}

Materials. All reagents were molecular biology grade from Sigma (St. Louis, MO) or Boehringer Mannheim (Indianapolis, IN), except where otherwise noted.

Preparation of ${ }^{35}$ S-labeled cRNA probes. DNA templates for riboprobe synthesis were prepared by the PCR using plasmid clones containing the full-length rat $\operatorname{Kv} \beta 1$ or $\operatorname{Kv} \beta 2$ cDNAs (Nakahira et al., 1996) or a partial Kv $\beta 2$ cDNA (K. Nakahira, S. Nawoschik, J. Trimmer, unpublished observations) as PCR templates. Two independent riboprobes targeted to unique, nonoverlapping regions of $\operatorname{Kv} \beta 1$ or $\operatorname{Kv} \beta 2$ were used in the present study. The probe sequences were checked versus the Genbank database to ensure that they only recognize the appropriate targets among all deposited sequences. To generate riboprobes for the $\operatorname{Kv} \beta 1$ subunit, one pair of oligonucleotide primers was designed to amplify a $264 \mathrm{bp}$ region spanning nucleotides -46 to 218 of the rat $\mathrm{Kv} \beta 1$ cDNA and, in addition, to add the promoter sequences for T3 RNA polymerase. These primers contained the following sequences: 5'-CGGATCCGCTGTGCTGTGGGGTTCTGAGAGGAC-3' (forward); 5'-AATTAACCCTCACTAAAGGGATATTTCATGCCAGTCTGCT-3' (reverse). The forward primer for this $\mathrm{Kv} \beta 1$ probe contained eight nucleotides of vector sequence at the $5^{\prime}$ end from the Bam HI site used for cloning. A second pair of oligonucleotide primers was designed to amplify a $271 \mathrm{bp}$ sequence spanning nucleotides -321 to -51 of the rat $\mathrm{Kv} \beta 1 \mathrm{cDNA}$ and, in addition, to add the promoter sequences for T3 RNA polymerase. These primers had the following sequences: 5'-CCTGACCACATGGATCTGGC-3' (forward); 5' -AATTAACCCTCACTAAAGGGCGGCAGAGGGTGAGACGTT-3' (reverse). To generate riboprobes for the $\mathrm{Kv} \beta 2$ subunit, one pair of primers was designed to amplify a $228 \mathrm{bp}$ fragment from the $3^{\prime}$ untranslated region (nucleotides 1130-1357) of the rat $\mathrm{Kv} \beta 2 \mathrm{cDNA}$ and, in addition, to add the promoter sequences for T3 RNA polymerase. These primers had the following sequences: 5'-CCCAGCTCGGACAGTTCCTGGTTCC-3' (forward); 5'-AATTAACCCTCACTAAAGGGGCATCCAGCGAGG AAGCGGC-3' (reverse). A second riboprobe for $\mathrm{Kv} \beta 2$ was generated using oligonucleotide primers designed to amplify a $300 \mathrm{bp}$ fragment spanning nucleotides $809-1108$ of the rat $\operatorname{Kv} \beta 2$ cDNA and, in addition, to add the promoter sequences for T3 RNA polymerase. These primers contained the following sequences: 5'-ACCAGTGGTTGAAGGACAAG-3' (forward); 5' AATTAACCCTCACTAAAGGGTGACTTAGGATCTATAGTCC-3' (reverse). All PCR products were gel purified on $1.5 \%$ low-melt agarose gels, and bands containing the $\mathrm{Kv} \beta 1$ or $\mathrm{Kv} \beta 2$ products were excised, phenol and phenol-chloroform extracted, and ethanol precipitated. The pellet then was dried and resuspended in $1 \times$ TE buffer containing (in mM): 10 Tris/ $\mathrm{HCl}, 1$ EDTA, pH 7.4. Fifty nanograms of DNA template were used for transcription reactions using ${ }^{35} \mathrm{~S}-\mathrm{CTP}$ (New England Nuclear, Boston, MA) and the Riboprobe Gemini System (Promega, Madison, WI). Probes were examined by Northern analysis of rat brain RNA and by Southern analysis of plasmids containing the $\operatorname{Kv} \beta 1$ and $\operatorname{Kv} \beta 2$ cDNAs. Each probe reacted with a single band of appropriate size on Northern blots and with only the appropriate cDNA on the plasmid Southern blots, indicating that these riboprobes specifically recognized $\operatorname{Kv} \beta 1$ and $\operatorname{Kv} \beta 2$ transcripts (data not shown).

In situ hybridization. Eight adult male Sprague-Dawley rats were used for analysis of $\operatorname{Kv} \beta 1$ and $\operatorname{Kv} \beta 2$ mRNA expression by in situ hybridization histochemistry. Animals were killed by asphyxiation with $\mathrm{CO}_{2}$, and the brains were removed, immediately frozen in a bed of pulverized dry ice, and stored at $-70^{\circ} \mathrm{C}$. Sections were cut at $10 \mu \mathrm{m}$ on a Hacker-Brights cryostat and thaw mounted onto chilled $\left(-20^{\circ} \mathrm{C}\right)$ slides coated with Vectabond reagent (Vector Labs, Burlingame, CA). All solutions were prepared in $\mathrm{dH}_{2} \mathrm{O}$ treated with $0.1 \%(\mathrm{v} / \mathrm{v})$ diethylpyrocarbonate and autoclaved. Sections were fixed by immersion in $4 \%$ paraformaldehyde in PBS, pH 7.4, then immersed sequentially in $2 \times$ SSC $(1 \times$ SSC is $0.150 \mathrm{M}$ sodium chloride, $0.015 \mathrm{M}$ sodium citrate), $\mathrm{dH}_{2} \mathrm{O}$, and $0.1 \mathrm{M}$ triethanolamine, $\mathrm{pH}$ 8.0. The sections then were acetylated by immersion in $0.1 \mathrm{M}$ triethanolamine containing $0.25 \%(\mathrm{v} / \mathrm{v})$ acetic anhydride; washed in $0.2 \times$
SSC; dehydrated in 50, 70, and 90\% ethanol; and rapidly dried. One $\mathrm{ml}$ of prehybridization solution containing $0.9 \mathrm{M} \mathrm{NaCl}, 1 \mathrm{~mm}$ EDTA, $5 \times$ Denhardt's solution, $0.25 \mathrm{mg} / \mathrm{ml}$ single-stranded herring sperm DNA (Gibco, Gaithersburg, MD), and 50\% deionized formamide (EM Sciences, Gibbstown, NJ) in $10 \mathrm{~mm}$ Tris, $\mathrm{pH}$ 7.6, was pipetted onto each slide, and the slides incubated for $3 \mathrm{hr}$ at $50^{\circ} \mathrm{C}$ in a humidified box. The sections then were dehydrated by immersion in 50, 70, and $90 \%$ ethanol and air dried.

Labeled riboprobes were denatured in a small volume $(100 \mu \mathrm{l})$ of hybridization solution containing $0.9 \mathrm{M} \mathrm{NaCl}, 1 \mathrm{~mm}$ EDTA, $1 \times$ Denhardt's solution, $0.1 \mathrm{mg} / \mathrm{ml}$ yeast tRNA, $0.1 \mathrm{mg} / \mathrm{ml}$ single-stranded salmon sperm DNA, dextran sulfate (10\%), 0.08\% BSA, 10 mm DTT (Boehringer Mannheim, Indianapolis, IN), and 50\% deionized formamide in 10 $\mathrm{mm}$ Tris, $\mathrm{pH} 7.6$, at $95^{\circ} \mathrm{C}(1 \mathrm{~min})$; placed on ice $(5 \mathrm{~min})$; and added at a final concentration of $50,000 \mathrm{cpm} / \mu \mathrm{l}$ to $10 \mathrm{ml}$ of prewarmed (to $55^{\circ} \mathrm{C}$ ) hybridization solution. The hybridization solution then was pipetted onto the sections and allowed to hybridize overnight at $55^{\circ} \mathrm{C}$ in a humidified chamber. The sections were subsequently washed once for $45 \mathrm{~min}$ at $37^{\circ} \mathrm{C}$ in $2 \times$ SSC containing $10 \mathrm{~mm}$ DTT, once for $30 \mathrm{~min}$ at $37^{\circ} \mathrm{C}$ in $1 \times \mathrm{SSC}$ containing $50 \%$ formamide, and once for $30 \mathrm{~min}$ at $37^{\circ} \mathrm{C}$ in $2 \times \mathrm{SSC}$. Single-stranded and nonspecifically hybridized riboprobe was digested by immersion in $10 \mathrm{~mm}$ Tris, $\mathrm{pH} 8.0$, containing bovine pancreas RNase A (Boehringer Mannheim) $(40 \mu \mathrm{g} / \mathrm{ml}), 0.5 \mathrm{M} \mathrm{NaCl}$, and $1 \mathrm{~mm}$ EDTA. The sections then were washed in $2 \times \mathrm{SSC}$ for $1 \mathrm{hr}$ at $60^{\circ} \mathrm{C}$, followed by $0.1 \times$ SSC containing $0.5 \%(\mathrm{w} / \mathrm{v})$ sodium thiosulfate for $2 \mathrm{hr}$ at $60^{\circ} \mathrm{C}$. The sections then were dehydrated in 50,70, and $90 \%$ ethanol containing 0.3 $\mathrm{M}$ ammonium acetate, and dried.

The slides then were loaded into X-ray cassettes and exposed to Hyperfilm $\beta$-Max (Amersham, Arlington Heights, IL) for 3-7 d. Once a satisfactory exposure was obtained, the slides were coated with nucleartrack emulsion (NTB-2) (Eastman Kodak, Rochester, NY) and exposed for $7-21 \mathrm{~d}$ at $4^{\circ} \mathrm{C}$. The emulsion autoradiograms were developed and fixed according to the manufacturer's instructions, and the underlying tissue sections were stained with hematoxylin.

To assess nonspecific labeling in the in situ hybridization procedure, a control probe was generated from a template provided in the Riboprobe Gemini System kit (Promega catalog \#P2651). This vector was linearized using ScaI, and transcribed using T3 RNA polymerase. The resulting transcription reaction generates two products, a $250 \mathrm{bp}$ and a $1525 \mathrm{bp}$ riboprobe, containing only vector sequence. This control probe mixture was labeled as described above and added to the hybridization solution at a final concentration of $50,000 \mathrm{cpm} / \mu \mathrm{l}$. No specific hybridization was observed in control sections; i.e., these sections gave a very weak uniform hybridization signal that did not follow neuroanatomical landmarks (data not shown).

Production of synthetic peptides and antibodies. Synthetic peptides corresponding to amino acids $7-28$ from the $N$ terminus of the rat $\mathrm{Kv} \beta 1$ polypeptide (CTEHNLKSRNGEDRLLSKQSST) (Rettig et al., 1994) and amino acids $1-17$ of the rat $\mathrm{Kv} \beta 2$ polypeptide (MYPESTTGSPARLSLRQC) (Rettig et al., 1994) were synthesized (Quality Controlled Biochemicals, Hopkinton, MA) and conjugated to keyhole limpet hemocyanin (KLH) (1 mg peptide/mg carrier protein) using sulfo- $m$ maleimidobenzoyl- $N$-hydroxysuccinimide ester (Pierce, Rockford, IL). These peptide/KLH conjugates were injected into rabbits for the production of polyclonal antisera (Pocono Rabbit Farm, Canadensis, PA), and into mice for the production of monoclonal antibodies (mAbs). Production of mAbs and purification of monoclonal immunoglobulins were performed essentially as described previously (Trimmer et al., 1985), and will be described in detail elsewhere (Z. Bekele-Arcuri, M. Matos, J. Trimmer, unpublished observations). For affinity purification of the polyclonal antibodies, the $\operatorname{Kv} \beta 1$ and $\operatorname{Kv} \beta 2$ peptides were conjugated to SulfoLink coupling gel (Pierce) via the terminal cysteine residues. Polyclonal antibodies were affinity purified from immune serum by standard procedures (Harlow and Lane, 1988).

Immunofluorescence. Immunofluorescence staining of transiently transfected cells expressing $\operatorname{Kv} \beta 1$ and $\operatorname{Kv} \beta 2$ was performed essentially as described previously (Shi et al., 1994). Briefly, green monkey fibroblast COS-1 cells were cultured on glass coverslips that had been previously coated with $25 \mu \mathrm{g} / \mathrm{ml}$ poly-L-lysine. For staining, cells were washed three times in ice-cold PBS, then fixed and permeabilized by treatment for $20 \mathrm{~min}$ at $4^{\circ} \mathrm{C}$ with a freshly prepared ice-cold fixative containing 3\% paraformaldehyde $/ 0.1 \%$ Triton X-100 in PBS. Cells then were washed three times in TBS containing $0.1 \%$ Triton X-100 (TBS-T), and nonspecific protein binding sites were blocked by incubation in TBS-T containing $4.5 \% \mathrm{w} / \mathrm{v}$ nonfat dry milk powder 
(Blotto-T) (Johnson et al., 1984). Cells then were incubated in primary antibodies diluted in Blotto- $\mathrm{T}$ for $1 \mathrm{hr}$ at room temperature, washed three times in Blotto-T for $30 \mathrm{~min}$ total, and incubated in the appropriate secondary antibodies for $30 \mathrm{~min}$. After three washes in TBS-T for 15 min total, cells were mounted in PBS medium containing $90 \%$ glycerol and $1 \mathrm{mg} / \mathrm{ml} p$-phenylenediamine and viewed on a Zeiss Axiophot microscope using epifluorescence illumination.

Brain membrane preparations. A crude synaptosomal membrane fraction was prepared from freshly dissected adult rat brains, essentially as described previously (Trimmer, 1991, 1993). Briefly, brains were homogenized in $0.3 \mathrm{~m}$ sucrose, $10 \mathrm{~mm}$ sodium phosphate, $\mathrm{pH} 7.4$, and $10 \mathrm{~mm}$ sodium fluoride, containing a protease inhibitor cocktail $(1 \mathrm{~mm}$ phenylmethyl sulfonyl fluoride, $1 \mu \mathrm{g} / \mathrm{ml}$ leupeptin, $2 \mu \mathrm{g} / \mathrm{ml}$ aprotinin, and 1 $\mu \mathrm{g} / \mathrm{ml}$ pepstatin). The resultant homogenate was centrifuged at $3,000 \times$ $g$ for $10 \mathrm{~min}$ to remove nuclei and cellular debris. The supernatant then was centrifuged at $45,000 \times g$ for $60 \mathrm{~min}$ to pellet the membranes. Aliquots of the membrane preparations were suspended in the homogenization buffer, and protein was determined using the BCA method (Pierce).

SDS/polyacrylamide gels and immunoblotting. For immunoblots, $50 \mu \mathrm{g}$ of membrane protein was added to SDS sample buffer, boiled, and fractionated on 7.5 or $12 \%$ SDS/polyacrylamide gels (Maizel, 1971). Disulfide bonds were reduced by the addition of $20 \mathrm{~mm}$ 2-mercaptoethanol to the sample buffer. Lauryl sulfate (Sigma) was the SDS source used for all SDS-PAGE (Shi et al., 1994). After electrophoretic transfer to nitrocellulose paper, the resulting blots were blocked in TBS containing 4\% low fat milk (Blotto) (Johnson et al., 1984), incubated in affinity-purified antibody diluted 1:50-1:100 in Blotto for 1 $\mathrm{hr}$ or undiluted $\mathrm{mAb}$ tissue culture supernatants, and washed three times in Blotto for 30 min total. Blots then were incubated in HRP-conjugated secondary antibody (1:2000 dilution in Blotto) (Cappel, West Chester, PA) for $1 \mathrm{hr}$ and then washed in TBS three times for $30 \mathrm{~min}$ total. The blots then were incubated in substrate for enhanced chemiluminescence (ECL) (Amersham, Arlington Heights, IL) for $1 \mathrm{~min}$ and autoradiographed on preflashed (to $\mathrm{OD}_{545}=0.15$ ) Kodak X-OMAT LS film.

Immunoprecipitation. Immunoprecipitation reactions were performed using detergent lysates of rat brain membranes. All procedures were performed at $4^{\circ} \mathrm{C}$. Membranes (1 $\mathrm{mg}$ membrane protein/tube) were solubilized to $1 \mathrm{ml}$ final volume/tube in lysis buffer (1\% Triton X-100, 0.15 $\mathrm{M} \mathrm{NaCl}, 1 \mathrm{~mm}$ EDTA, $10 \mathrm{~mm}$ sodium azide, $10 \mathrm{~mm}$ Tris/HCl, $\mathrm{pH}$ 8.0, containing a protease inhibitor cocktail (see above). Affinity-purified antibodies were added and the samples incubated for $2 \mathrm{hr}$ on a rotator, followed by addition of $20 \mu \mathrm{l}$ of a $50 \%$ suspension of protein A sepharose and additional incubation for $45 \mathrm{~min}$. After incubation, protein A sepharose was centrifuged at $10,000 \times g$ for $20 \mathrm{sec}$, and the resulting pellets were washed by resuspension and centrifugation six times with lysis buffer. The final pellets were resuspended in $50 \mu \mathrm{l}$ reducing sample buffer, and $20 \mu$ lelectrophoresed on 12\% SDS-PAGE and subjected to immunoblotting as described above.

Immunohistochemistry. Twelve adult male Sprague-Dawley rats were deeply anesthetized with sodium pentobarbital $(60 \mathrm{mg} / \mathrm{kg}$, i.p.) and perfused through the ascending aorta with $150 \mathrm{ml}$ of $0.9 \%$ saline, followed by $500 \mathrm{ml}$ of fixative containing freshly prepared $4 \%$ paraformaldehyde in $0.1 \mathrm{M} \mathrm{NaPO}_{4}$ buffer, $\mathrm{pH} 7.4$ (PB). The brains were removed, cryoprotected for $18-48 \mathrm{hr}$ in $20 \%$ sucrose in $\mathrm{PB}$, frozen in a bed of pulverized dry ice, and then cut into $35-\mu \mathrm{m}$-thick sections on a sliding microtome. Consecutive 1-in-10 series of sections were collected in 0.05 M PB and processed for light microscopic immunohistochemistry as described previously (Rhodes et al., 1995). Affinity-purified rabbit polyclonal anti-Kv $\beta 1$ and rabbit anti-Kv $\beta 2$ antibodies were used at dilutions of 1:1500 and 1:4000, respectively. Mouse mAbs (purified $\mathrm{IgG}$ fractions and tissue culture supernatants) raised against $\operatorname{Kv} \beta 1$ (clone $\mathrm{K} 9 / 40$ ) and $\mathrm{Kv} \beta 2$ (clone K17/70) were used at dilutions of 1:100-1:1500. To verify the specificity of the immunohistochemical reactions, some sections were processed either without addition of the primary antibody or using antibodies incubated previously $(1 \mathrm{hr})$ in vehicle containing an excess of the synthetic peptide/BSA antigen $(5-25 \mu \mathrm{g} / \mathrm{ml})$. No specific staining was observed in these control sections (data not shown).

Analysis of sections processed for in situ hybridization and immunohistochemistry was performed using a Zeiss Axiophot photomicroscope. Low-magnification photographs of immunohistochemically stained sections and autoradiograms generated on film were taken using a Nikon Multiphot macrophotography system.

\section{RESULTS}

\section{Localization of $\operatorname{Kv} \beta 1$ and $\operatorname{Kv} \beta 2$ mRNA} General features

Analysis of autoradiograms prepared on film indicated that the $\mathrm{Kv} \beta 1$ and $\mathrm{Kv} \beta 2$ mRNAs are widely and heterogeneously expressed in adult rat brain (Table 1). The pair of riboprobes for $\mathrm{Kv} \beta 1$ generated patterns of hybridization signal that were indistinguishable from one another, as did the pair of riboprobes for $\mathrm{Kv} \beta 2$. Taken together with the result of Northern and Southern blotting using these probes, this result strongly suggests that the riboprobes used in the present study specifically reveal the presence of $\operatorname{Kv} \beta 1$ or $\operatorname{Kv} \beta 2$ mRNA.

A very high density of $\operatorname{Kv} \beta 1$ expression was observed in the striatum, nucleus accumbens, olfactory tubercle, CA1 subfield of the hippocampus, and entorhinal and posterior cingulate cortices, and in several midbrain and brainstem motor nuclei (Fig. 1). Intermediate levels of $\mathrm{Kv} \beta 1$ expression were observed in the piriform cortex; neocortex; medial septal-diagonal band complex; anterior, mediodorsal, and ventral tier thalamic nuclei; and the cerebellar cortex and deep nuclei. Intermediate levels of $\mathrm{Kv} \beta 1$ expression also were observed in the laterodorsal, ventral posteromedial (VPM), ventral posterolateral (VPL), and dorsal lateral geniculate, and medial geniculate nuclei of the thalamus. Low levels of $\operatorname{Kv} \beta 1$ expression were observed in the globus pallidus and hypothalamus. The highest levels of $\mathrm{Kv} \beta 2$ expression were observed in the piriform cortex, hippocampal formation, and in layer II of the entorhinal cortex, with somewhat lower levels in the neocortex, medial septal-diagonal band complex, and the anterior, VPM, and VPL nuclei of the thalamus. Low and levels of $\mathrm{Kv} \beta 2$ expression were observed in the remaining thalamic nuclei and in the striatum, globus pallidus, and hypothalamus.

\section{Neocortex and hippocampus}

Examination of high-resolution emulsion autoradiograms of sections processed to visualize hybridization to $\operatorname{Kv} \beta 1$ and $\operatorname{Kv} \beta 2$ mRNAs indicated that these two transcripts are expressed within cellular profiles with the size and morphology of neurons as opposed to glial cells (Fig. 2). Kv $\beta 1$ mRNA was expressed in large pyramidal cells in the deep half of layer III and in layers V and VI. Very high levels of $\mathrm{Kv} \beta 1$ mRNA were observed in small to medium interneurons in cortical layers II, III, V, and VI. Interestingly, high levels of $\operatorname{Kv} \beta 1$ mRNA also were observed in small cells juxtaposed to the subcortical white matter (Fig. 1). In virtually all regions of the neocortex, $\mathrm{Kv} \beta 2$ mRNA was highly expressed in pyramidal cells in layers II, III, V, and VI. In proisocortical areas such as the entorhinal and cingulate cortices, $\mathrm{Kv} \beta 1$ and $\mathrm{Kv} \beta 2$ mRNA also were highly expressed in large multipolar neurons in layer II (Fig. 2).

In the hippocampus, $\mathrm{Kv} \beta 1 \mathrm{mRNA}$ was expressed in dentate granule cells and in pyramidal cells of all subfields. However, pyramidal cells in the CA1 subfield expressed higher levels of $\mathrm{Kv} \beta 1$ mRNA than the adjacent CA2 subfield and subiculum (Fig. 1 ). In addition, $\mathrm{Kv} \beta 1$ was expressed in large interneurons located in stratum oriens and radiatum of all subfields. The distribution of $\operatorname{Kv} \beta 2$ mRNA was strikingly similar to that observed for $\operatorname{Kv} \beta 1$, with the exception that there appeared to be a uniformly high density of $\mathrm{Kv} \beta 2$ expression across all subfields, and $\mathrm{Kv} \beta 2$ mRNA did not appear to be expressed at an appreciably greater density in hippocampal interneurons. 
Table 1. Distribution of $\mathrm{Kv} \beta 1$ and $\mathrm{Kv} \beta 2$ mRNA and protein in rat brain

\begin{tabular}{|c|c|c|c|c|c|c|}
\hline Region & Subfield/lamina/sublamina & & $\begin{array}{l}\mathrm{Kv} \beta 1 \\
\mathrm{mRNA}\end{array}$ & $\begin{array}{l}\mathrm{Kv} \beta 2 \\
\text { mRNA }\end{array}$ & $\begin{array}{l}\mathrm{Kv} \beta 1 \\
\text { Immunoreactivity }\end{array}$ & $\begin{array}{l}\mathrm{Kv} \beta 2 \\
\text { Immunoreactivity }\end{array}$ \\
\hline \multirow[t]{7}{*}{ Cortex } & & & ++ & + & + & + \\
\hline & I & & ++ & +++ & ++ & +++ \\
\hline & II & & +++ & +++ & ++ & +++ \\
\hline & III & & +++ & ++ & +++ & +++ \\
\hline & IV & & +++ & ++ & ++ & ++ \\
\hline & $\mathrm{V}$ & & ++++ & ++++ & ++++ & ++++ \\
\hline & VI & & ++++ & ++++ & +++ & +++ \\
\hline \multicolumn{7}{|l|}{ Hippocampus } \\
\hline & Dentate gyrus & & & & & \\
\hline & & Infragranular & ++ & +++ & + & + \\
\hline & & Granule cell & +++ & ++++ & ++ & ++ \\
\hline & & Inner third & + & + & + & + \\
\hline & & Middle third & + & + & ++ & +++ \\
\hline & & Outer third & + & + & + & ++ \\
\hline & CA1 & & & & & \\
\hline & & S. oriens & ++ & ++ & ++ & ++ \\
\hline & & S. pyramidale & ++++ & +++++ & ++ & ++++ \\
\hline & & S. radiatum & ++ & ++ & ++ & +++ \\
\hline & & S. moleculare & + & + & + & + \\
\hline \multicolumn{7}{|l|}{ Striatum } \\
\hline & Caudate & & +++++ & ++ & ++ & ++ \\
\hline & Accumbens & & +++++ & ++ & ++ & ++ \\
\hline & Olfactory tubercle & & +++++ & ++ & ++ & ++ \\
\hline & Globus pallidus & & ++ & ++ & ++++ & ++++ \\
\hline \multicolumn{7}{|l|}{ Basal forebrain } \\
\hline & Medial septal n. & & +++ & +++ & +++ & +++ \\
\hline & Lateral septal n. & & + & + & + & + \\
\hline & Diagonal band vert. & & +++ & +++ & +++ & +++ \\
\hline & Diagonal band hor. & & +++ & +++ & +++ & +++ \\
\hline & Nucleus basalis & & +++ & +++ & +++ & +++ \\
\hline \multicolumn{7}{|l|}{ Amygdala } \\
\hline & Basolateral n. & & +++ & ++++ & ++ & ++ \\
\hline \multicolumn{7}{|l|}{ Thalamus } \\
\hline & Anterior $\mathrm{n}$. & & +++ & ++++ & ++ & ++ \\
\hline & Lateral n. & & ++ & ++ & +++ & +++ \\
\hline & Laterodorsal n. & & ++ & ++ & ++ & ++ \\
\hline & $\mathrm{VL}$ & & +++ & +++ & +++ & ++ \\
\hline & VPM & & +++ & ++ & +++ & ++ \\
\hline & VPL & & +++ & +++ & +++ & ++ \\
\hline & Lateral geniculate $\mathrm{n}$. & & ++ & +++ & +++ & ++ \\
\hline & Medial geniculate $n$. & & ++ & ++ & ++ & ++ \\
\hline Hypothalamus & & & ++ & ++ & ++ & ++ \\
\hline \multicolumn{7}{|l|}{ Habenula } \\
\hline & Medial n. & & + & ++ & ++ & + \\
\hline & Lateral n. & & ++ & ++ & ++ & + \\
\hline \multicolumn{7}{|l|}{ Midbrain } \\
\hline & Sup. colliculus & & +++ & ++ & +++ & ++ \\
\hline & Inf. colliculus & & ++++ & +++ & ++ & ++ \\
\hline & Substantia nigra & & & & & \\
\hline & Pars compacta & & ++ & ++ & ++ & ++ \\
\hline & Pars reticulata & & + & + & ++++ & ++++ \\
\hline & Red n. & & ++++ & ++++ & +++++ & +++++ \\
\hline & nIII & & +++ & +++ & +++ & +++ \\
\hline & $\mathrm{nIV}$ & & +++ & +++ & ++++ & ++++ \\
\hline \multicolumn{7}{|l|}{ Pons } \\
\hline & $\mathrm{mnV}$ & & +++ & +++ & ++++ & ++++ \\
\hline & nVI & & +++ & +++ & ++++ & ++++ \\
\hline & nVII & & +++ & +++ & ++++ & ++++ \\
\hline & nVIII & & ++ & ++ & ++ & ++ \\
\hline \multicolumn{7}{|l|}{ Medulla } \\
\hline & mnIX & & +++ & +++ & ++++ & ++++ \\
\hline & $\mathrm{mnX}$ & & +++ & +++ & ++++ & ++++ \\
\hline & $\operatorname{mnXI}$ & & +++ & +++ & ++++ & ++++ \\
\hline & mnXII & & +++ & +++ & ++++ & ++++ \\
\hline \multicolumn{7}{|l|}{ Cerebellum } \\
\hline & Purkinje cells & & ++++ & ++ & +++ & +++ \\
\hline & Granule cells & & ++ & ++ & + & + \\
\hline & Interneurons & & + & ++ & + & ++ \\
\hline & Deep nuclei & & +++ & +++ & +++ & +++ \\
\hline
\end{tabular}




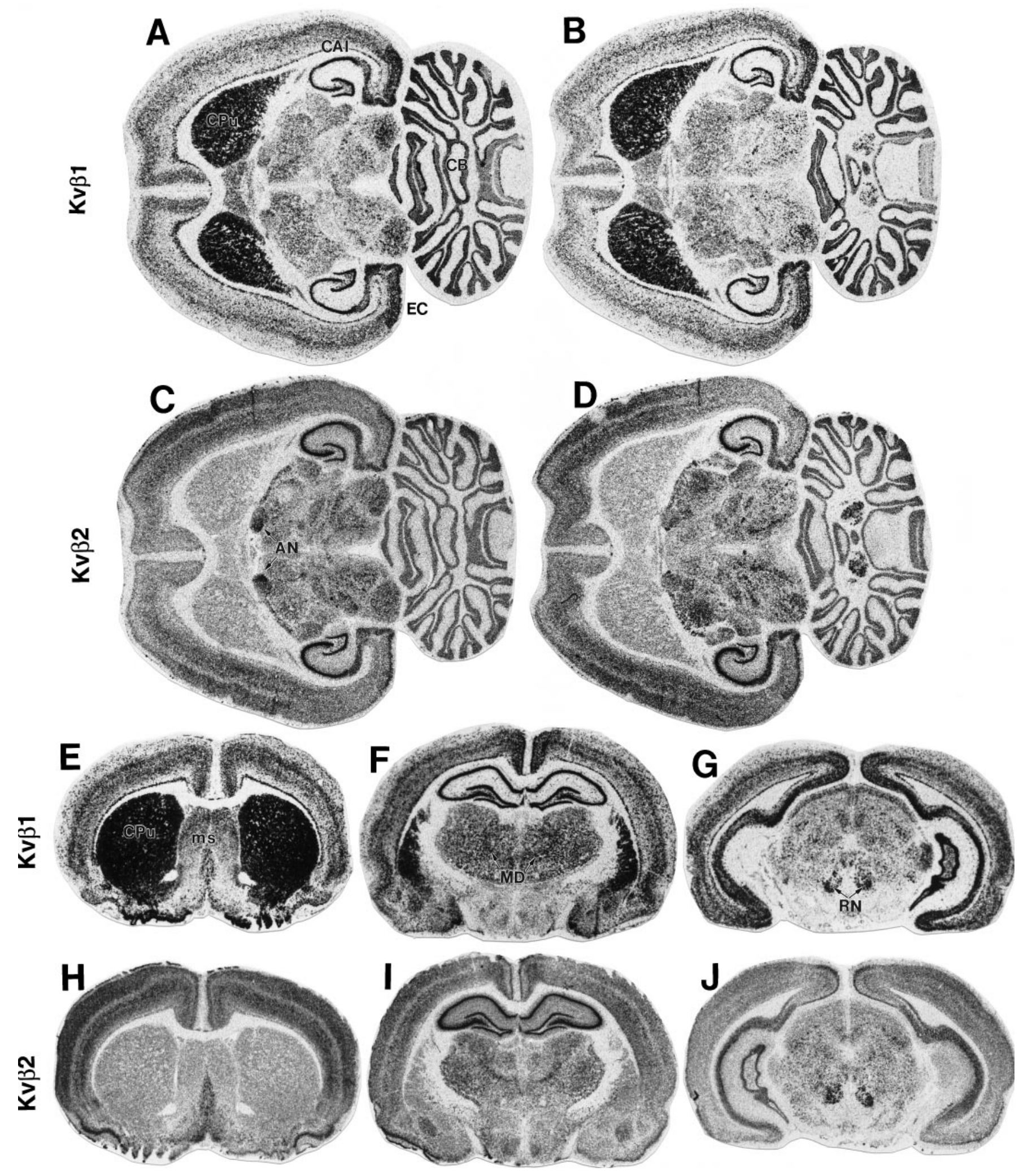

Figure 1. Expression of $\mathrm{Kv} \beta 1$ and $\mathrm{Kv} \beta 2$ mRNA in adult rat brain. Horizontal and coronal sections of rat brain were processed by in situ hybridization histochemistry to localize $\operatorname{Kv} \beta 1(A, B, E-G)$ and $\operatorname{Kv} \beta 2(C, D, H-J)$ mRNA. Areas containing a high density of hybridization signal appear dark in these bright-field images. The autoradiograms in $A-D$ were exposed for $3 \mathrm{~d}$, whereas those in $E-J$ were exposed for $7 \mathrm{~d}$. At the shorter exposure time, subtle differences in expression levels are more easily discernible. For example, there is a comparatively greater density of Kv $\beta 1$ mRNA in the CA1 subfield of the hippocampus as compared with the adjacent CA3 subfield $(B)$. $C A 1$, Hippocampal subfield; $C B$, cerebellum; $C P u$, caudate putamen; $E C$, entorhinal cortex; $R N$, red nucleus; $m s$, medial septal nuclei; $A N$, anterior thalamic nucleus; $M D$, mediodorsal thalamic nucleus. 

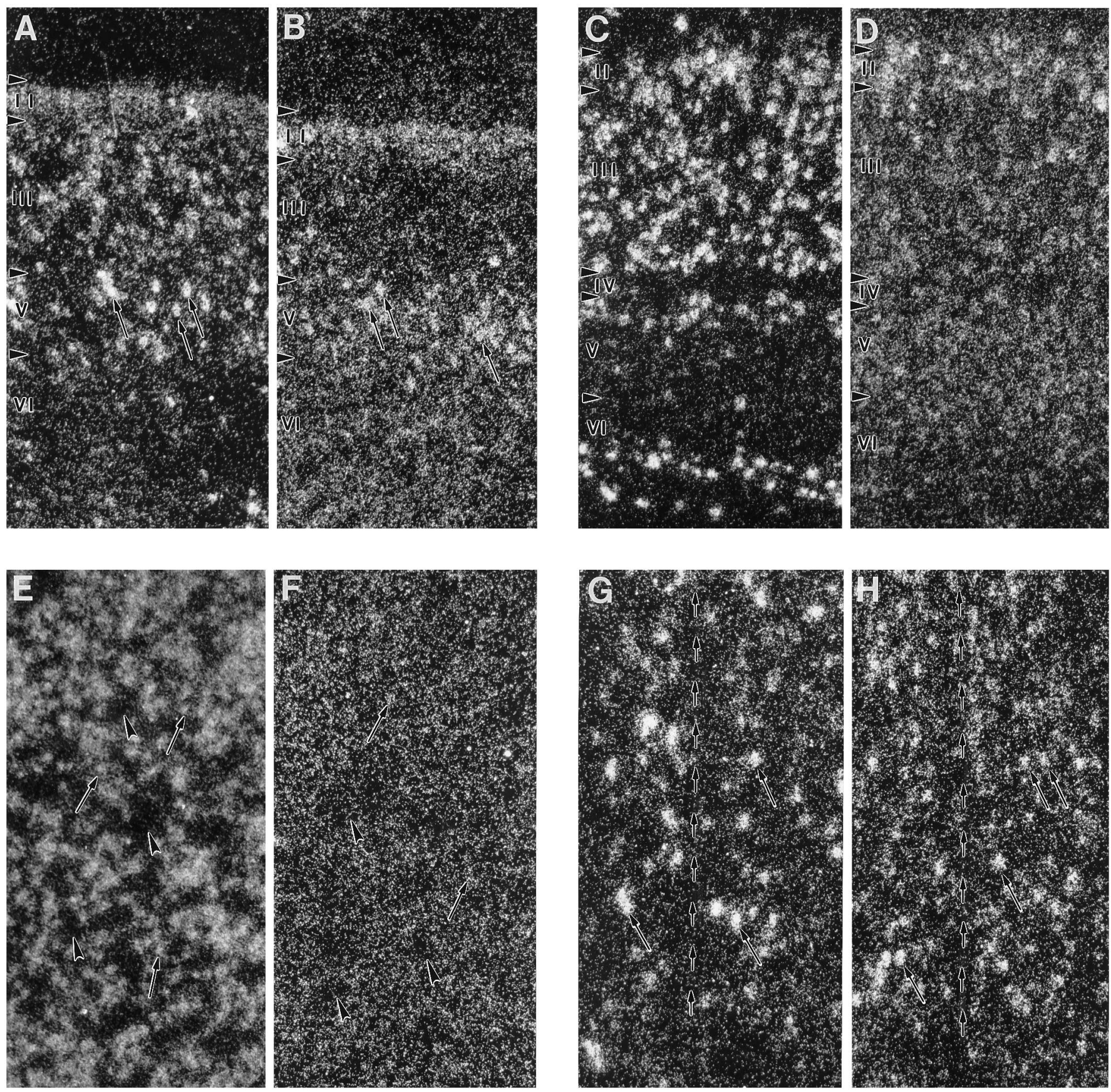

Figure 2. Cellular localization of $\mathrm{Kv} \beta 1$ and $\mathrm{Kv} \beta 2 \mathrm{mRNA}$ expression. Emulsion autoradiograms were prepared to localize $\mathrm{Kv} \beta 1$ and $\mathrm{Kv} \beta 2 \mathrm{mRNA}$ within individual cells. Cells containing a high density of mRNA contain a correspondingly high density of silver grains, which appear as bright spots in these dark-field images. In posterior cingulate cortex (area 23$), \operatorname{Kv} \beta 1 \mathrm{mRNA}(A)$ is highly expressed in many small cells in layers II and III and larger cells in layer V (arrows), whereas $\mathrm{Kv} \beta 2(B)$ is expressed predominantly in small cells in layer II and larger cells in layer $\mathrm{V}$ (arrows). In the entorhinal cortex, Kv $\beta 1$ mRNA $(C)$ is expressed in large and small cells in layers II, III, V, and VI, whereas Kv $\beta 2$ mRNA $(D)$ is expressed at high density in layer II cells and with a lower density in cells in the remaining layers of this structure. In the caudate nucleus, there is a very high level of Kv $\beta 1$ expression $(E)$ and a lower level of $\operatorname{Kv} \beta 2$ expression $(F)$ in virtually all cells (arrows). The bundles of myelinated axons that course through this structure do not contain hybridization signal (arrowheads). In the basal forebrain, $\operatorname{Kv} \beta 1(G)$ and $\operatorname{Kv} \beta 2(H)$ mRNAs are expressed in large cells (arrows) with the distribution and frequency characteristic of the large cholinergic neurons present in this region. The short arrows in $G$ and $H$ mark the midline of the brain.

\section{Striatum and basal forebrain}

The greatest density of $\operatorname{Kv} \beta 1$ expression was observed in the caudate putamen, nucleus accumbens, and olfactory tubercle. Virtually all neurons in these structures expressed extremely high levels of $\operatorname{Kv} \beta 1$ mRNA (Figs. 1, $2 E$ ). Kv $\beta 1$ mRNA also was highly expressed in the medial septal nuclei and the vertical and hori- zontal limbs of the diagonal band of Broca in a distribution that closely resembled the distribution of cholinergic neurons in these structures (Fig. 2G) (Mesulam et al., 1983). In contrast to $\operatorname{Kv} \beta 1$, there was a low level of $\mathrm{Kv} \beta 2$ expression in the caudate putamen, nucleus accumbens, and olfactory tubercle (Figs. 1, $2 F$ ). However, there was a high level of $\mathrm{Kv} \beta 2$ expression in the medial septal and 
diagonal band nuclei in a pattern that overlapped with, but was somewhat more extensive than, that observed for $\operatorname{Kv} \beta 1$ (Figs. 1, 2H).

\section{Thalamus and hypothalamus}

A moderate density of $\mathrm{Kv} \beta 1$ expression was observed throughout the thalamus, with a somewhat greater density in the anterior, mediodorsal, and entopeduncular nuclei (Fig. 1), and a moderate density in the laterodorsal, VPM, and VPL nuclei. A low level of $\mathrm{Kv} \beta 1$ expression was observed in the hypothalamus, but with a somewhat more intense hybridization signal in the ventromedial hypothalamic nucleus. A low to moderate level of $\mathrm{Kv} \beta 2$ expression was observed throughout the thalamus, with a somewhat greater density in the anterior, mediodorsal, paracentral, and ventroposterior nuclei. Low levels of $\mathrm{Kv} \beta 2$ expression also were observed in the hypothalamus, however, as for $\mathrm{Kv} \beta 1$, there was a somewhat greater density of $\mathrm{Kv} \beta 2$ expression in the ventromedial nucleus.

\section{Midbrain}

Several midbrain motor nuclei, including the red nucleus and all cranial nerve nuclei, contained a very high density of $\operatorname{Kv} \beta 1$ and $\operatorname{Kv} \beta 2$ expression (Fig. 1). In addition, cells in the superficial and deep layers of the superior and inferior colliculi, the periaqueductal gray, and the pars compacta and pars reticulata of the substantia nigra expressed intermediate levels of $\mathrm{Kv} \beta 1$ mRNA. Similarly, large neurons in the deep layers of the superior and inferior colliculi expressed moderate levels of Kv $\beta 2$ mRNA, and cells scattered throughout the substantia nigra pars compacta and pars reticulata expressed moderate to low levels of $\operatorname{Kv} \beta 2$ mRNA (Fig. 1).

\section{Cerebellum and brainstem}

In the cerebellar cortex, Purkinje cells and granule cells displayed high and moderate levels of $\operatorname{Kv} \beta 1$ expression, respectively, and small neurons scattered throughout the molecular layer expressed much lower levels of $\mathrm{Kv} \beta 1 \mathrm{mRNA}$. In contrast, Purkinje cells and granule cells displayed intermediate levels of $\mathrm{Kv} \beta 2$ expression, and small neurons with a size and distribution similar to basket cells expressed moderate levels of $\mathrm{Kv} \beta 2$ mRNA. Large neurons in all deep cerebellar nuclei expressed moderate levels of $\operatorname{Kv} \beta 1$ and $\mathrm{Kv} \beta 2$ mRNA (Fig. 1).

In the pons and medulla, all cranial nerve sensory and motor nuclei displayed moderate to high levels of $\operatorname{Kv} \beta 1$ and $\operatorname{Kv} \beta 2$ expression. In addition, mRNA for both $\beta$ subunits was highly expressed in large pontine and medullary reticular neurons and in neurons of the superior and inferior olivary complexes.

\section{Generation and characterization of $\operatorname{Kv} \beta 1-$ and $K v \beta 2-$ specific polyclonal and mAbs}

A polyclonal antiserum was produced by the immunization of rabbits with a synthetic $\mathrm{Kv} \beta 1$ peptide immunogen, corresponding to N-terminal amino acids $7-28$ of the deduced rat brain $\mathrm{Kv} \beta 1$ sequence (Rettig et al., 1994). This sequence is not present in the deduced sequence of the rat brain $\operatorname{Kv} \beta 2 \beta$ subunit, although some overlap is seen to a recently identified rat brain $\operatorname{Kv} \beta 3 \beta$ subunit (11/22 positions identical with changes spread throughout the sequences) (Heinemann et al., 1995; Pongs, 1995). Thus, it is likely that antibodies generated to this peptide are specific for $\mathrm{Kv} \beta 1$. Rabbit polyclonal antibodies raised against this peptide exhibited a high titer against the peptide on ELISA assays and displayed a monospecific reaction on immunoblot assays versus rat brain membranes to a $44 \mathrm{kDa}$ polypeptide (Fig. 3). That this peptide was $\operatorname{Kv} \beta 1$ was supported by analysis of $\operatorname{Kv} \beta 1$ and $\operatorname{Kv} \beta 2$
Transfected
Cell Lysates Cell Lysates
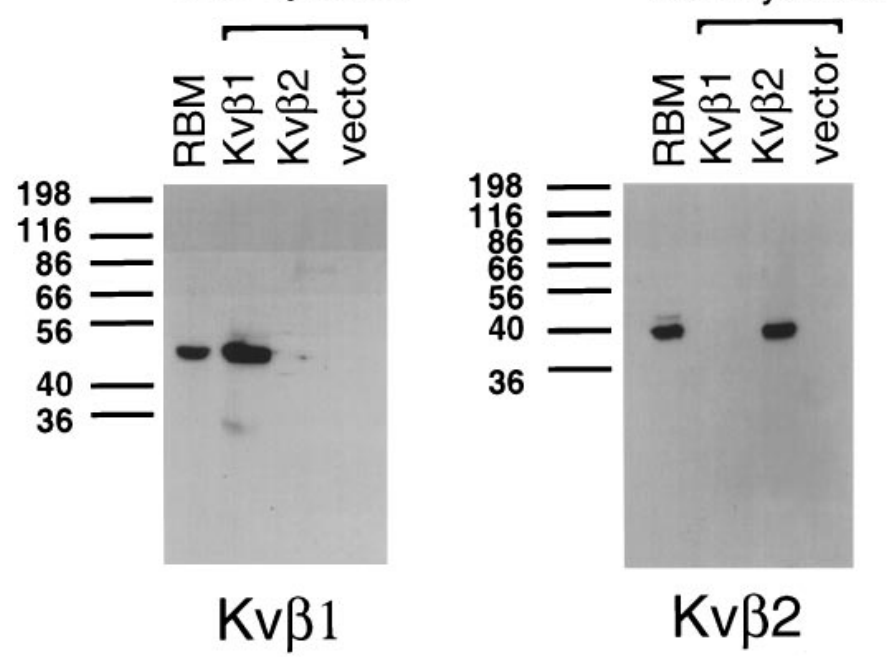

Figure 3. Immunoblot analyses of the $\operatorname{Kv} \beta 1$ and $\operatorname{Kv} \beta 2 \beta$-subunit polypeptides in rat brain membranes and in transfected COS- 1 cells. Crude rat brain membranes $(R B M)(50 \mu \mathrm{g})$ and the detergent extracts of COS-1 cells transfected with $\mathrm{Kv} \beta 1 / \mathrm{RBG} 4(K v \beta 1), \mathrm{Kv} \beta 2 / \mathrm{RBG} 4(K v \beta 2)$, or RBG4 alone (vector) were fractionated on a $12.5 \%$ SDS gel and transferred to nitrocellulose, and the resultant immunoblot probed with either rabbit anti-Kv $\beta 1$ polyclonal antibody at 1:50 (left) or mouse anti-Kv $\beta 2 \mathrm{mAb}$ $\mathrm{K} 17 / 70$ tissue culture supernatant neat (right). Signals were visualized using ECL (left, $30 \mathrm{~min}$; right, $1 \mathrm{~min}$ ). Numbers on left refer to mobility of prestained molecular weight standards.

expressed in COS-1 cells, which showed that the expressed recombinant $\operatorname{Kv} \beta 1$ polypeptide shared immunoreactivity and electrophoretic mobility with the putative rat brain $\mathrm{Kv} \beta 1$ polypeptide (Fig. 3). No corresponding immunoreactivity was seen to the recombinant $38 \mathrm{kDa} \mathrm{Kv} \beta 2$ polypeptide expressed in COS- 1 cells or present in the crude rat brain membranes on the same immunoblot (Fig. 3). Immunofluorescence staining of transfected COS- 1 cells revealed a similar pattern of immunoreactivity in that the anti-Kv $\beta 1$ antibody exhibited a strong immunofluorescence staining of $\operatorname{Kv} \beta 1-$, but not $\operatorname{Kv} \beta 2-$, transfected cells (Fig. 4).

mAbs generated against the same Kv $\beta 1$-specific peptide exhibited similar properties. All of the mAbs exhibited strong reactions in ELISA assays against the $\operatorname{Kv} \beta 1$ peptide immunogen and in immunofluorescence staining of COS-1 cells expressing recombinant $\operatorname{Kv} \beta 1$ polypeptide (Fig. 4). Staining was not observed in nontransfected or Kv $\beta 2$-transfected cells (Fig. 4). Immunoblot analysis of crude rat brain membranes revealed that none of the mAbs isolated recognized the SDS-denatured rat brain $\mathrm{Kv} \beta 1$ polypeptide, although specific immunoreactivity was seen to the recombinant $\mathrm{Kv} \beta 1$ (but not $\mathrm{Kv} \beta 2$ ) polypeptide present in COS-1 cell extracts, perhaps because of the higher expression levels of $\mathrm{Kv} \beta 1$ in these extracts compared with that observed in rat brain membranes (data not shown). All of these mAbs, and the rabbit polyclonal antibody, selectively immunoprecipitate the recombinant $\mathrm{Kv} \beta 1$ polypeptide present in ${ }^{35} \mathrm{~S}$-methionine labeled COS-1 cell extracts (data not shown). Additional details on the generation and characterization of these mAbs will be described elsewhere.

A polyclonal antiserum was produced by the immunization of rabbits with a synthetic $\mathrm{Kv} \beta 2$ peptide immunogen, corresponding to $\mathrm{N}$-terminal amino acids $1-17$ of the deduced rat brain $\mathrm{Kv} \beta 2$ sequence (Rettig et al., 1994). This sequence is not present in the 

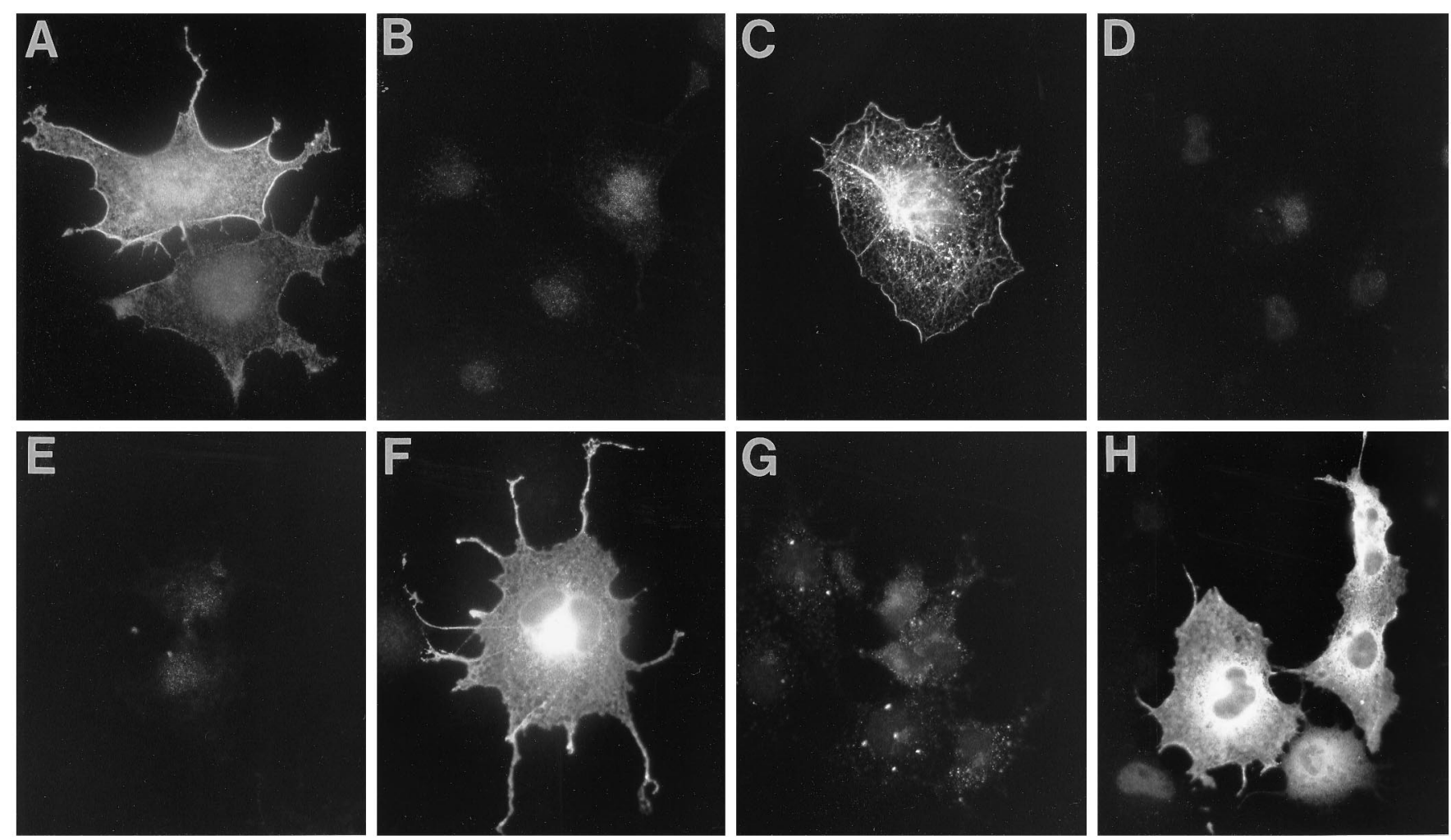

Figure 4. Analysis of antibody specificity. Immunofluorescence staining of $\operatorname{Kv} \beta 1$ and $\operatorname{Kv} \beta 2 \beta$ subunits expressed in COS- 1 cells. COS- 1 cells were transfected with $\mathrm{Kv} \beta 1 / \mathrm{RBG} 4(A-D)$ or $\mathrm{Kv} \beta 2 / \mathrm{RBG} 4(E-H)$ cDNAs. Transfected cells then were fixed, permeabilized, and incubated with rabbit anti-Kv $\beta 1$ polyclonal antibody at $1: 100(A, E)$, rabbit anti-Kv $\beta 2$ polyclonal antibody at $1: 200(B, F)$, mouse anti-Kv $\beta 1 \mathrm{mAb} \mathrm{K} 9 / 40$ at $1: 2(C, G)$, or mouse anti-Kv $\beta 2$ mAb K17/70 at 1:2 $(D, H)$. Cells then were incubated with Texas Red-conjugated anti-rabbit $(A, B, E, F)$ or anti-mouse $(C, D, G, H)$ secondary antibody.

deduced sequence of the rat brain $\operatorname{Kv} \beta 1$ or $\operatorname{Kv} \beta 3 \beta$ subunit (Heinemann et al., 1995; Pongs, 1995). Thus, it is likely that antibodies generated to this peptide would be specific for $\mathrm{Kv} \beta 2$. Rabbit polyclonal antibodies raised against this peptide exhibited a high titer against the $\operatorname{Kv} \beta 2$ peptide on ELISA assays and displayed a monospecific reaction on immunoblot assays versus rat brain membranes to a $38 \mathrm{kDa}$ polypeptide (Fig. 3). Additional immunoreactivity was exhibited to a minor, $41 \mathrm{kDa}$ polypeptide (Fig. 3) that is also recognized by the pan- $\beta$-subunit antibody (Rhodes et al., 1995). The molecular identity of this $41 \mathrm{kDa}$ polypeptide is not known; however, the fact that it exhibits immunoreactivity to both the N-terminally directed anti-Kv $\beta 2$ antibody and the $\mathrm{C}$-terminally directed pan- $\beta$ antibody indicates that it is either a post-translational variant of $\mathrm{Kv} \beta 2$ or an alternative splice variant of the $\mathrm{Kv} \beta 2$ gene. That the $38 \mathrm{kDa}$ polypeptide was $\mathrm{Kv} \beta 2$ was supported by analysis of $\mathrm{Kv} \beta 1$ and $\mathrm{Kv} \beta 2$ expressed in COS- 1 cells, which showed that the expressed recombinant $\mathrm{Kv} \beta 2$ polypeptide shared immunoreactivity and electrophoretic mobility $\left(M_{\mathrm{r}}=38 \mathrm{kDa}\right)$ with the putative rat brain $\mathrm{Kv} \beta 2$ polypeptide (the $41 \mathrm{kDa}$ variant was not detected). No corresponding immunoreactivity was seen to the recombinant $44 \mathrm{kDa} \mathrm{Kv} \beta 1$ polypeptide expressed in COS- 1 cells or present in the crude rat brain membranes on the same immunoblot (Fig. 3). Immunofluorescence staining of transfected COS- 1 cells revealed a similar pattern of immunoreactivity in that the anti-Kv $\beta 2$ antibody exhibited a strong immunofluorescence staining of $\operatorname{Kv} \beta 2$ - but not $\operatorname{Kv} \beta 1$ transfected cells (Fig. 4).

Anti-Kv $\beta 2$ mAbs were generated against a glutathione- $S$ transferase fusion protein containing the entire $\mathrm{Kv} \beta 2$ polypeptide. All of the N-terminally directed mAbs exhibited monospecific immunofluorescence staining of COS-1 cells expressing recombinant $\operatorname{Kv} \beta 2$, but not $\operatorname{Kv} \beta 1$, polypeptide (Fig. 4). No staining to untransfected cells was seen (Fig. 4). Immunoblot analysis of crude rat brain membranes revealed that only the K17/70 mAb recognizes the SDS-denatured rat brain $\operatorname{Kv} \beta 2$ polypeptide and recombinant $\operatorname{Kv} \beta 2$ (but not $\operatorname{Kv} \beta 1$ ) polypeptide present in COS-1 cell extracts (Fig. 3). Additional details on the generation and characterization of these mAbs will be described elsewhere.

\section{Reciprocal co-immunoprecipitations: subunit association}

To determine whether $\operatorname{Kv} \beta 1$ and $\operatorname{Kv} \beta 2$ were present in the same rat brain $\mathrm{K}^{+}$channel complexes, we performed reciprocal coimmunoprecipitation experiments with the anti-Kv $\beta 1$ and anti$\operatorname{Kv} \beta 2$ antibodies. Detergent lysates were prepared from rat brain membranes under conditions shown previously to preserve $\alpha$-or $\beta$-subunit interactions (Sheng et al., 1993; Wang et al., 1993; Rhodes et al., 1995; Nakahira et al., 1996; Shi et al., 1996). These lysates then were used in immunoprecipitation reactions performed with the anti-Kv $\beta 1$ and anti-Kv $\beta 2$ polyclonal antibodies and with a pan- $\beta$ polyclonal antibody that recognizes both $\mathrm{Kv} \beta 1$ and $\operatorname{Kv} \beta 2$ (Rhodes et al., 1995). Immunoprecipitations also were performed using a polyclonal antibody against the Kv2.1 $\alpha$ subunit, which should not co-immunoprecipitate either of these $\beta$ subunits (Rhodes et al., 1995). Immunoprecipitation reactions then were subjected to immunoblot analyses to assay for the presence of $\operatorname{Kv} \beta 1$ with the anti-Kv $\beta 1$ polyclonal antibody, for $\mathrm{Kv} \beta 2$ with the $\mathrm{K} 17 / 70 \mathrm{mAb}$, and for the $\beta$-subunit-associated $\alpha$ subunit Kv1.2 with the Kv1.2C polyclonal antibody (Rhodes et al., 1995). 


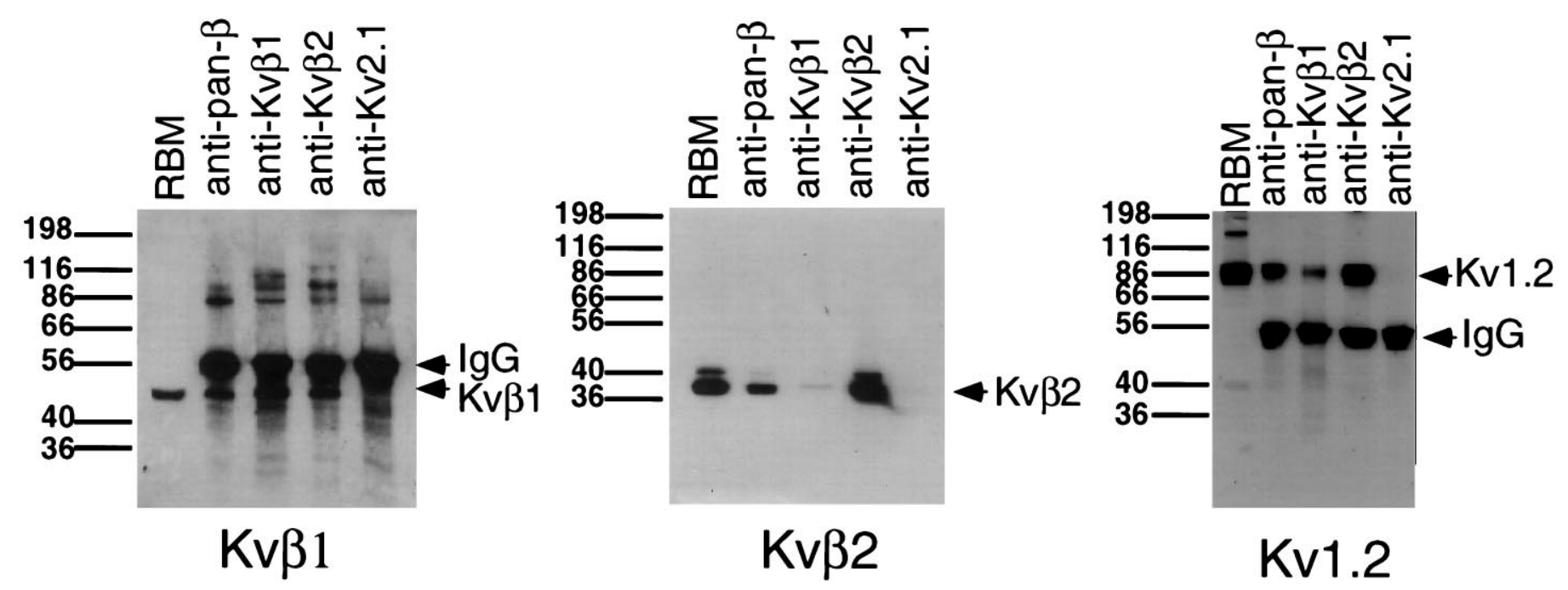

Figure 5. Presence of $\mathrm{Kv} \beta 1$ and $\mathrm{Kv} \beta 2$ in rat brain $\mathrm{K}^{+}$channel complexes. Samples of adult rat brain membranes $(R B M)(60 \mu \mathrm{g})$ and aliquots of products of immunoprecipitation reactions from detergent extracts of $500 \mu \mathrm{g}$ RBM with polyclonal antibodies specific for both $\mathrm{Kv} \beta 1$ and $\mathrm{Kv} \beta 2$ (pan- $\beta$, $1: 100$ ), $\mathrm{Kv} \beta 1$ (anti-Kv $\beta 1,1: 200$ ), $\mathrm{Kv} \beta 2$ (anti-Kv $\beta 2,1: 500$ ), or the Kv2.1 $\alpha$ subunit (anti-Kv2.1, 1:200) were size fractionated by 12.5\% SDS-PAGE. Samples were transferred to nitrocellulose and probed with rabbit anti-Kv $\beta 1$ polyclonal antibody at 1:50 (left panel), mouse anti-Kv $\beta 2 \mathrm{mAb} \mathrm{K} 17 / 70$ neat (middle panel), or rabbit anti-Kv1.2 polyclonal antibody at 1:100 (right panel). Bound antibody detected by ECL-autoradiography for $40 \mathrm{~min}$ (left panel) or 3 min (middle and right panels). Arrows point to mobility of the heavy-chain polypeptides of the rabbit immunoglobulins used in the immunoprecipitation reactions and of the respective $\mathrm{K}^{+}$channel polypeptides; numbers at left of the panels denote $M_{\mathrm{r}}$ of prestained molecular weight standards. Bands at $\sim 50 \mathrm{kDa}$ (left and right panels) are heavy chains of rabbit IgG used for immunoprecipitations, which react with anti-rabbit, but not anti-mouse, secondary antibody.

As expected, the anti-Kv $\beta 1$ antibody immunoprecipitated the $44 \mathrm{kDa} \mathrm{Kv} \beta 1$ polypeptide from these rat brain extracts (Fig. 5), as did the anti-pan- $\beta$ polyclonal antibody, whereas the anti-Kv2.1 antibody did not immunoprecipitate detectable amounts of $\mathrm{Kv} \beta 1$. That the same amount of rabbit IgG was precipitated in each of these reactions is demonstrated by the $\sim 50 \mathrm{kDa}$ band present in each immunoprecipitation lane that is attributable to immunoreactivity of the rabbit IgG from the immunoprecipitating antibody, with the anti-rabbit secondary antibody used to develop the immunoblots. Surprisingly, levels of $\mathrm{Kv} \beta 1$ comparable to those observed in the anti-Kv $\beta 1$ reaction were co-immunoprecipitated by the anti-Kv $\beta 2$ polyclonal antibody. Because these immunoprecipitation reactions were performed under conditions in which antigen is limiting, these data demonstrate that a large proportion of the $\operatorname{Kv} \beta 1$ found in rat brain is present in complexes that also contain the $\operatorname{Kv} \beta 2 \beta$ subunit (Fig. 5).

These same immunoprecipitation reactions then were assayed for the presence of $\mathrm{Kv} \beta 2$; because these immunoblots were performed with the anti-Kv $\beta 2$ mouse $\mathrm{mAb} \mathrm{K} 17 / 70$, the rabbit $\mathrm{IgG}$ bands typically seen in the immunoprecipitation reactions are not visualized. The rabbit anti-Kv $\beta 2$ polyclonal antibody was able to immunoprecipitate the $38 \mathrm{kDa} \mathrm{Kv} \beta 2$ polypeptide present in these samples. Comparable amounts of $\operatorname{Kv} \beta 2$ also were observed in the immunoprecipitation reaction performed with the anti-pan- $\beta$ polyclonal antibody (Fig. 5). Low levels of $\operatorname{Kv} \beta 2$ also were observed in the reactions performed with the anti-Kv $\beta 1$ antibody, confirming the observation above and indicating that individual $\mathrm{K}^{+}$channel complexes may contain both of these $\beta$-subunit polypeptides. As expected, the anti-Kv2.1 antibody also was unable to co-immunoprecipitate detectable amounts of $\mathrm{Kv} \beta 2$. All of the immunoprecipitation reactions performed with the anti- $\beta$ subunit antibodies contained Kv1.2 (Fig. 5), showing that each of these antibodies could effectively recognize and isolate intact $\mathrm{K}^{+}$ channel complexes.

\section{Immunohistochemical localization of $\operatorname{Kv} \beta 1$ and $\operatorname{Kv} \beta 2$}

Analysis of immunohistochemically stained sections indicated that $\operatorname{Kv} \beta 1$ and $\operatorname{Kv} \beta 2$ are present in cell bodies, dendrites, the juxtaparanodal regions of myelinated axons, and terminal fields of several major projection systems. The pattern of immunohistochemical staining observed with mAbs and polyclonal antibodies to the same $\beta$ subunit was indistinguishable. The areal and laminar distribution of labeled cells suggests and comparisons of sections processed by in situ hybridization and immunohistochemistry suggest that cells expressing $\operatorname{Kv} \beta 1$ and $\mathrm{Kv} \beta 2$ mRNA also are immunoreactive for the corresponding proteins. Regions containing moderate to intense immunoreactivity for $\operatorname{Kv} \beta 1$ and $\operatorname{Kv} \beta 2$ were the neocortex, hippocampus, piriform cortex, striatum, thalamus, cerebellum, cranial nerve nuclei, and virtually all major white matter pathways. Although it is beyond the scope of this paper to provide a comprehensive account of $\beta$-subunit immunoreactivity in every brain region, the salient features of the immunohistochemical staining are described below and summarized in Table 1.

\section{Neocortex and hippocampus}

In the neocortex, immunoreactivity for $\mathrm{Kv} \beta 1$ was concentrated within pyramidal cells and was particularly intense in smaller bipolar and multipolar interneurons in layers II, III, V, and VI (Fig. $6 A$ ). In each of these cell populations, immunoreactivity for $\mathrm{Kv} \beta 1$ was concentrated within the cell body and proximal portions of the dendritic tree. Immunoreactivity for $\mathrm{Kv} \beta 2$ also was observed in cortical pyramidal cells, with very intense labeling of large pyramidal cells in layer $\mathrm{V}$ (Fig. $6 C$ ). However, in contrast to immunoreactivity for $\mathrm{Kv} \beta 1$, immunoreactivity for $\mathrm{Kv} \beta 2$ was concentrated throughout the entire apical dendrite of layer $\mathrm{V}$ pyramidal cells, including fine branches and apical tufts. Interestingly, the small interneurons that displayed strong immunoreactivity for $\mathrm{Kv} \beta 1$ were not intensely immunoreactive for $\mathrm{Kv} \beta 2$. In addition to 

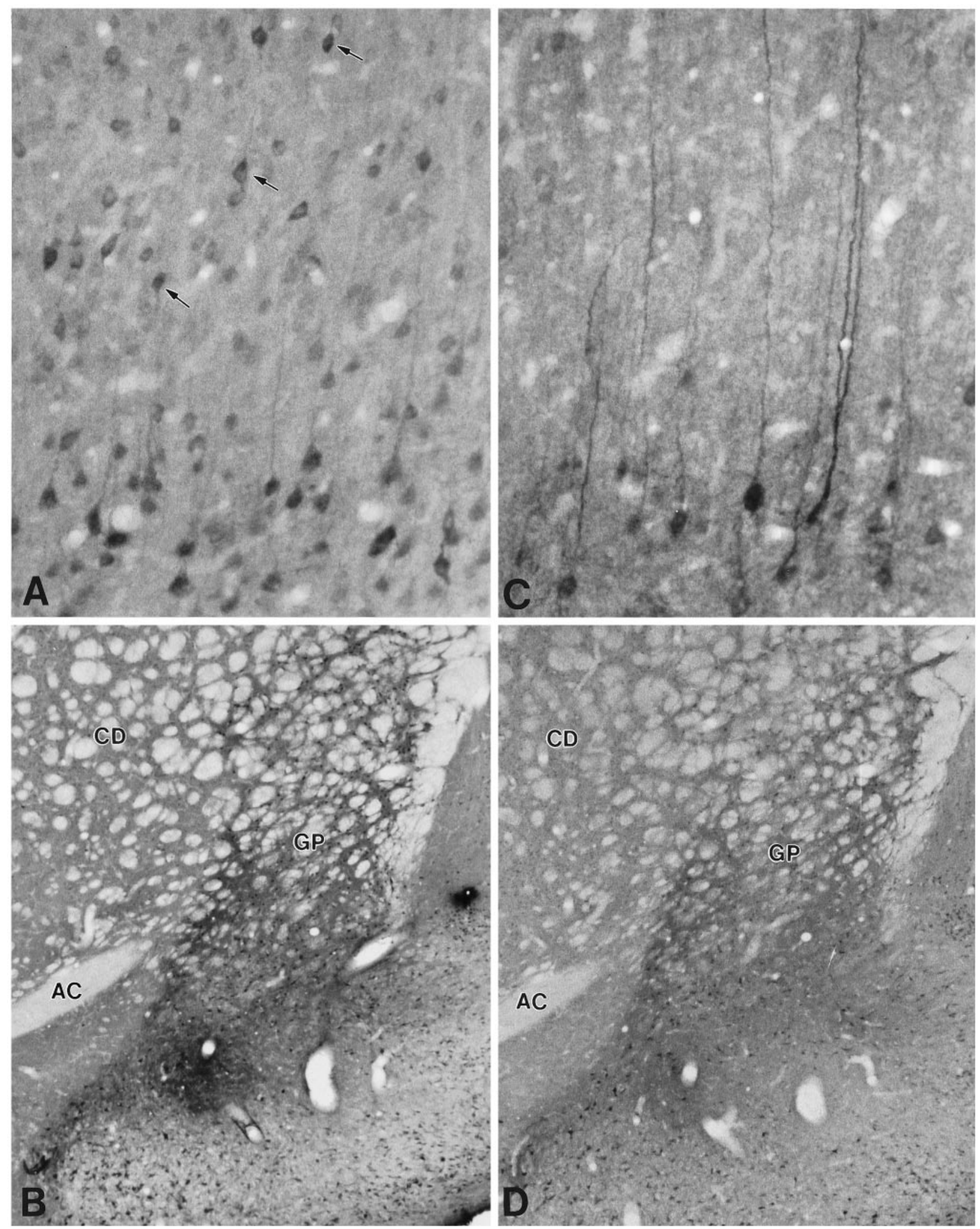

Figure 6. Immunohistochemical localization of $\mathrm{Kv} \beta 1$ and $\mathrm{Kv} \beta 2$ in the cerebral cortex and striatum. In parietal cortex, immunoreactivity for $\mathrm{Kv} \beta 1$ (K9/40 $\mathrm{mAb})(A)$ is concentrated in large pyramidal cells in layer $\mathrm{V}$ and in small interneurons (arrows) concentrated primarily in layers II and III. Immunoreactivity for $\operatorname{Kv} \beta 2$ (affinity-purified polyclonal antibody) $(C)$ is concentrated in the somas and apical dendrites of layer $\mathrm{V}$ pyramidal cells. The small interneurons that contain a high density of immunoreactivity for $\operatorname{Kv} \beta 1$ contain a much lower density of immunoreactivity for $\mathrm{Kv} \beta 2$. In the striatum, there is a very high density of immunoreactivity for $\operatorname{Kv} \beta 1(B)$ and $\operatorname{Kv} \beta 2(D)$ in the globus pallidus $(G P)$ and a lower density in the caudate nucleus $(C D)$. In the globus pallidus, immunoreactivity for $\operatorname{Kv} \beta 1$ and $\operatorname{Kv} \beta 2$ is primarily concentrated in terminal fields and is present in both the supra- and subcommissural segments. $A C$, Anterior commissure. 
the somatodendritic staining described above, in many cortical regions, moderate to intense immunoreactivity for $\operatorname{Kv} \beta 1$ and $\mathrm{Kv} \beta 2$ was observed in axonal profiles coursing throughout the cortical neuropil and in a pattern consistent with labeling of terminal fields. This pattern of labeling was particularly intense in the piriform, posterior cingulate, retrosplenial, and entorhinal cortices. Myelinated axons in the subcortical white matter as well as other regions also contained immunoreactivity for $\operatorname{Kv} \beta 1$ and $\mathrm{Kv} \beta 2$. The staining in these fibers was discontinuous, with a greater density of reaction product in the juxtaparanodal segments at nodes of Ranvier (Shi et al., 1996).

In the hippocampal formation, there was a heterogeneous distribution of $\operatorname{Kv} \beta 1$ and $\operatorname{Kv} \beta 2$ immunoreactivity with moderate to intense staining of granule and pyramidal cell somata (data not shown). Immunoreactivity for $\operatorname{Kv} \beta 1$ and $\mathrm{Kv} \beta 2$ also was concentrated within interneurons in stratum oriens and stratum radiatum of the CA1-CA3 subfields. In the dentate gyrus, granule cells contained a moderate density of $\operatorname{Kv} \beta 1$ and $\mathrm{Kv} \beta 2$ immunoreactivity. In these cells, staining was concentrated in the cell soma and did not extend into dendritic branches, suggesting that this staining is associated with $\beta$ subunits synthesized within these cells. In the molecular layer of the dentate gyrus, there was a distinct band of $\operatorname{Kv} \beta 1$ and $\mathrm{Kv} \beta 2$ immunoreactivity in the middle third and somewhat less intense labeling in the outer third. As described previously (Rhodes et al., 1995), the location of this band of intense immunoreactivity corresponds closely to the termination zone of the medial perforant path. In the CA subfields and subiculum, immunoreactivity for $\operatorname{Kv} \beta 1$ and $\operatorname{Kv} \beta 2$ was distributed diffusely throughout the neuropil, with a greater density in stratum radiatum and stratum oriens than in stratum moleculare, and immunoreactivity for $\operatorname{Kv} \beta 2$, but not $\operatorname{Kv} \beta 1$, was concentrated throughout the apical dendrites and apical dendritic tufts of hippocampal pyramidal cells. In the CA3 subfield, there was a moderate density of $\operatorname{Kv} \beta 1$ immunoreactivity in the mossy fiber zone.

\section{Striatum and basal forebrain}

In the caudate nucleus and nucleus accumbens, there was a moderate density of immunoreactivity for $\operatorname{Kv} \beta 1$ and $\operatorname{Kv} \beta 2$ within neurons of all sizes and morphologies and distributed diffusely throughout the neuropil. Interestingly, there was a higher density of immunoreactivity for $\operatorname{Kv} \beta 1$ and $\operatorname{Kv} \beta 2$ in bundles of axons coursing through the ventromedial portion of the caudate nucleus than in similar fiber bundles in the dorsolateral component of this structure. These fibers appeared to originate from cells within the caudate nucleus and could be followed in consecutive sections to their apparent termination throughout the supra- and subcommissural segments of the globus pallidus (Fig. $6 B, D$ ). Additional fibers showing intense immunoreactivity for $\operatorname{Kv} \beta 1$ and $\operatorname{Kv} \beta 2$ appeared to continue beyond the globus pallidus and run through the medial forebrain bundle and cerebral peduncle to terminate within the substantia nigra pars reticulata (Fig. $7 A, C$ ). Intense terminal-field labeling for $\operatorname{Kv} \beta 1$ and $\operatorname{Kv} \beta 2$ also was observed in the nucleus accumbens and olfactory tubercle, and in the deep half of the molecular layer of pyriform cortex.

In the medial septal and diagonal band nuclei, immunoreactivity for $\operatorname{Kv} \beta 1$ and $\operatorname{Kv} \beta 1$ was present in the somatodendritic compartments of magnocellular neurons. These neurons formed a continuous column of cells extending through the medial septum and vertical and horizontal limbs of the diagonal band and into the magnocellular neurons of the nucleus basalis of Meynert. This pattern of $\operatorname{Kv} \beta 1$ and $K v \beta 2$ immunoreactivity was virtually identical to the distribution of $\operatorname{Kv} \beta 1$ and $\operatorname{Kv} \beta 2$ mRNA and is very similar to the distribution and characteristic morphology of basal forebrain cholinergic neurons (Mesulam et al., 1983).

\section{Thalamus}

Many cells within various thalamic nuclei were immunoreactive for $\operatorname{Kv} \beta 1$ and $\operatorname{Kv} \beta 2$. The distribution of labeled cells corresponded closely to the pattern of expression $\operatorname{Kv} \beta 1$ and $\operatorname{Kv} \beta 2$ mRNA. In virtually all of these cells, a large proportion of the immunoreactivity was concentrated within the somatic and dendritic cytoplasm, suggesting that this staining is associated with the $\beta$-subunit polypeptides not yet transported to a distinct plasma membrane domain.

\section{Cerebellum}

In the cerebellum, immunoreactivity for $\operatorname{Kv} \beta 1$ and $\operatorname{Kv} \beta 2$ was concentrated within the cell bodies and dendrites of Purkinje cells and was distributed diffusely and with moderate intensity throughout the molecular layer (Fig. $7 B, D$ ). Immunoreactivity for $\mathrm{Kv} \beta 2$ also was present in the axon terminals of basket cells. These basket-cell terminals form a characteristic plexus surrounding the initial segment of Purkinje cell axons and have been shown previously to contain intense immunoreactivity for Kv1.1 and Kv1.2 $\alpha$ subunits (McNamara et al., 1993; Wang et al., 1993, 1994; Rhodes et al., 1995; Shi et al., 1996). Numerous fine-caliber axons within the granule cell layer also contained immunoreactivity for $\mathrm{Kv} \beta 1$ and $\operatorname{Kv} \beta 2$, as did large neurons within the deep cerebellar nuclei. The axons in the granule cell layer appeared to originate from Purkinje cells and frequently appeared to emerge from the core of labeling of the basket-cell terminal plexus. Large-caliber myelinated axons in the cerebellar white matter also contained intense immunoreactivity for $\operatorname{Kv} \beta 1$ and $\operatorname{Kv} \beta 2$. As described above, this immunoreactivity was strikingly discontinuous, with intense staining in patches juxtaposed to nodes of Ranvier (Shi et al., 1996).

\section{Midbrain and brainstem}

Large motor and sensory neurons within structures such as the red nucleus and all cranial nerve sensory and motor nuclei contained moderate to intense immunoreactivity for $\operatorname{Kv} \beta 1$ and Kv $\beta 2$ (Fig. 6A,C). In addition, neurons within the substantia nigra pars reticulata and in the deep layers of the superior colliculus were immunoreactive for these two $\beta$-subunit polypeptides. Large neurons within the midbrain and pontine reticular formation and inferior olivary complex were moderately to intensely labeled by both anti- $\beta$-subunit antibodies, as were axons within midbrain and brainstem white matter pathways and cranial nerve efferents.

\section{DISCUSSION}

Molecular, immunological, and neuroanatomical techniques were used to examine the expression, distribution, and co-association of two voltage-gated $\mathrm{K}^{+}$channel $\beta$ subunits in adult rat brain. Although the relative density of $\operatorname{Kv} \beta 1$ and $\operatorname{Kv} \beta 2$ expression and immunoreactivity differs considerably across brain regions, the expression of these two subunits shows substantial overlap, and in many cell populations the respective mRNAs and polypeptides probably co-localize. The riboprobes used in the present study reacted with single bands by Northern and Southern analysis, and their specificity is supported by the observation that two independent riboprobes targeted to nonoverlapping sequences of the target mRNA gave identical hybridization patterns. Moreover, the 

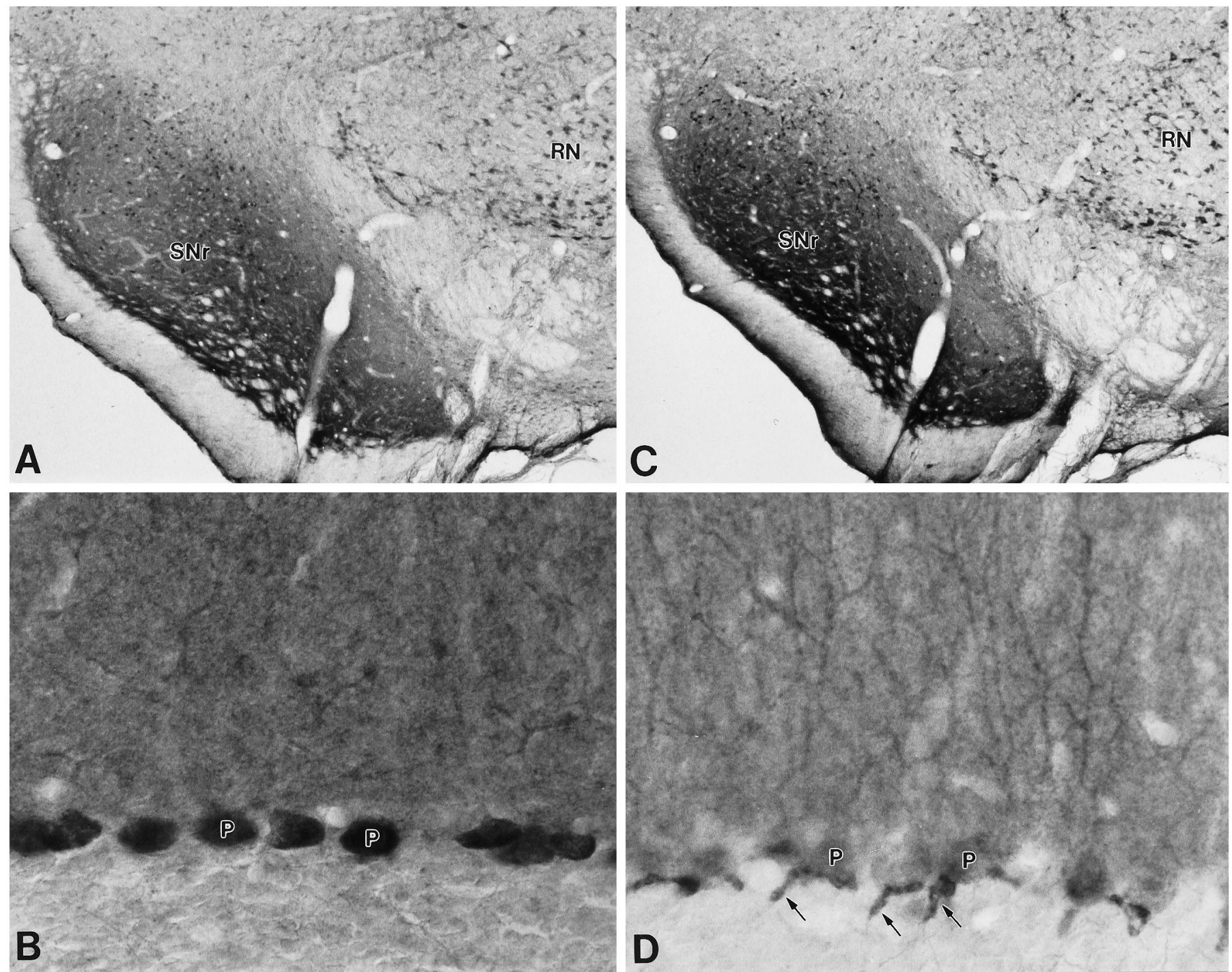

Figure 7. Immunohistochemical localization of $\mathrm{Kv} \beta 1$ and $\mathrm{Kv} \beta 2$ in the midbrain and cerebellum. In the midbrain, immunoreactivity for $\mathrm{Kv} \beta 1$ (K9/40 $\mathrm{mAb})(A)$ and $\operatorname{Kv} \beta 2$ (affinity-purified polyclonal antibody) $(C)$ is concentrated in terminal fields in the pars reticulata of the substantia nigra $(S N r)$ and in large neurons in the red nucleus $(R N)$. In the cerebellar cortex, immunoreactivity for $\operatorname{Kv} \beta 1(B)$ and $\operatorname{Kv} \beta 2(D)$ is concentrated in the cell bodies of Purkinje cells $(P)$ and in terminal fields throughout the molecular layer. Immunoreactivity for $\mathrm{Kv} \beta 2$ also is concentrated in the dendrites of Purkinje cells and in the axon terminals of basket cells, which form a characteristic synaptic plexus (arrows) that terminates on the initial segment of Purkinje cell axons.

pattern of immunoreactivity revealed by $\operatorname{Kv} \beta 1$ - and $\operatorname{Kv} \beta 2$-specific antibodies is consistent with localization of the respective polypeptides to the cell bodies, dendrites, or terminals of cells expressing the corresponding mRNA. Antibodies raised against unique N-terminal sequences of $\operatorname{Kv} \beta 1$ and $\operatorname{Kv} \beta 2$ reacted with 44 $\mathrm{kDa}$ and $38 \mathrm{kDa}$ polypeptides, respectively, in membranes prepared from rat brain and transfected COS cells; in brain, the 38 $\mathrm{kDa} \mathrm{Kv} \beta 2$ polypeptide is far more abundant. On the basis of reciprocal co-immunoprecipitation experiments, it appears that almost all channel complexes containing $\mathrm{Kv} \beta 1$ also contain $\mathrm{Kv} \beta 2$.

Using subtype-specific anti- $\beta$-subunit antibodies, we unambiguously identified the $\mathrm{Kv} \beta 1$ and $\mathrm{Kv} \beta 2$ polypeptides in rat brain. We based this identification on their reaction with antibodies made to unique regions of the deduced amino acid sequence and their co-migration on SDS gels with the recombinant protein expressed in transfected cells. Together, these results indicate that in rat brain, $\mathrm{Kv} \beta 1$ is a relatively low-abundance polypeptide of $M_{\mathrm{r}}=44$ $\mathrm{kDa}$, whereas $\mathrm{Kv} \beta 2$ is an abundant polypeptide of $M_{\mathrm{r}}=38 \mathrm{kDa}$.
Subsequent analyses of the $M_{\mathrm{r}}=44 \mathrm{kDa} \operatorname{Kv} \beta 1$ and $M_{\mathrm{r}}=38 \mathrm{kDa}$ $\mathrm{Kv} \beta 2$ polypeptide pools in rat brain membranes using a polyclonal antibody raised against a $\mathrm{C}$-terminal peptide conserved in both $\beta$ subunits ("pan- $\beta$ " antibody) (Rhodes et al., 1995) reveal a striking difference in the relative abundance of these two subunits. Quantitative analysis of immunoblots performed using the pan- $\beta$ subunit antibody, which recognizes both $\operatorname{Kv} \beta 1$ and $\operatorname{Kv} \beta 2$, shows that $\operatorname{Kv} \beta 2$ is $\sim 50$-fold more abundant than $\operatorname{Kv} \beta 1$ in rat brain membranes, supporting the model we initially proposed (Rhodes et al., 1995) that $\operatorname{Kv} \beta 2$ was by far the more abundant $\beta$ subunit subtype in brain. In addition, most $\operatorname{Kv} \beta 1$ appears to be present in complexes that also contain $\mathrm{Kv} \beta 2$, as evidenced by the fact that $\mathrm{Kv} \beta 1$-containing complexes are co-immunoprecipitated using a $\mathrm{Kv} \beta 2$-specific antibody. A small portion of the total $\mathrm{Kv} \beta 2$ pool in brain is present in these complexes, as evidenced by the small amount of $\mathrm{Kv} \beta 2$ in immunoprecipitations performed using the anti-Kv $\beta 1$ antibody, thus most of the $\operatorname{Kv} \beta 2$ in brain appears to exist in complexes lacking $\operatorname{Kv} \beta 1$. Conversely, it appears that the 


\section{RAT BRAIN $\beta$-SUBUNIT POOL}

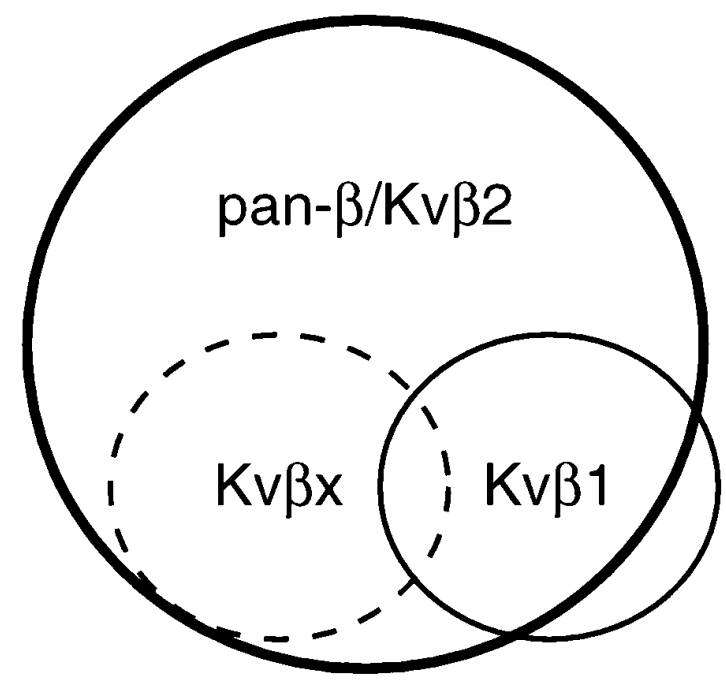

Figure 8. Hypothetical model of $\beta$-subunit associations in rat brain. The total rat brain $\beta$-subunit pool contains at least three $\beta$-subunit isoforms, designated $K v \beta 1, K v \beta 2$, and $K v \beta X$ in this Venn diagram. Immunoreactivity observed using $\operatorname{Kv} \beta 2$-specific antibodies recapitulates virtually the entire pattern and extent of immunoreactivity revealed using the pan- $\beta$ antibody (Rhodes et al., 1995), suggesting that $\mathrm{Kv} \beta 2$ is present in virtually all $\beta$ subunit-containing $\mathrm{K}^{+}$channel complexes. In contrast, immunoreactivity for $\operatorname{Kv} \beta 1$ is present in a small proportion of pan- $\beta / \operatorname{Kv} \beta 2$ immunoreactive structures. Because the $\mathrm{C}$-terminal epitope contained within the pan- $\beta$ antibody is present in all cloned $\operatorname{Kv} \beta$ subunits, it is likely that these $\beta$-subunit isoforms (designated $K v \beta X$ ) also will associate with a subset of the total brain $\beta$-subunit-containing complexes, i.e., in complexes that also contain $\operatorname{Kv} \beta 2$.

small amount of $\operatorname{Kv} \beta 1$ present in brain exists in complexes containing $\mathrm{Kv} \beta 2$; very few "pure" $\mathrm{Kv} \beta 1$ complexes are present.

Comparison of immunohistochemical staining patterns observed in the present study with those obtained using the pan- $\beta$ antibody (Rhodes et al., 1995) suggests that the immunoreactivity for $\operatorname{Kv} \beta 2$ recapitulates virtually the entire pattern and extent of immunoreactivity observed using the pan- $\beta$ antibody. If we assume that pan- $\beta$ staining represents the total $\beta$-subunit pool associated with Shaker $\alpha$ subunits, then we can assign $\operatorname{Kv} \beta 2$ as the major component of this pool. In addition, we can assign $\mathrm{Kv} \beta 1$ as a comparatively minor subcomponent, found predominantly in channel complexes that also contain $\mathrm{Kv} \beta 2$ (Fig. 8). On the basis of this analysis, we also can speculate that in brain, the distribution of other $\beta$-subunit isoforms containing this conserved C-terminal epitope (England et al., 1995a,b; Heinemann et al., 1995; Majumder et al., 1995; Morales et al., 1995) will show considerable overlap with that observed using the pan- $\beta$ and $\operatorname{Kv} \beta 2$-specific antibodies, and that these other $\beta$ subunits will be present in rat brain $\mathrm{K}^{+}$channel complexes in association with $\mathrm{Kv} \beta 2$.

The pattern of $\mathrm{Kv} \beta 1$ expression reported here is virtually identical to that reported for $\operatorname{Kv} \beta 1$ mRNA by Rettig et al. (1994). Their data and ours indicated that $\operatorname{Kv} \beta 1$ is highly expressed in the cortical interneurons; basal ganglia; limbic cortical regions such as the hippocampus, posterior cingulate, and entorhinal cortex; and brainstem and cerebellum. In the majority of regions, immunoreactivity for $\operatorname{Kv} \beta 1$ is concentrated at the terminals of cells expressing $\operatorname{Kv} \beta 1$ mRNA. The very high levels of $\operatorname{Kv} \beta 1$ expression in the caudate putamen corresponded well to the high density of $\operatorname{Kv} \beta 1$ immunoreactivity in terminal fields in the globus pallidus and substantia nigra and, similarly, the high levels of $\operatorname{Kv} \beta 1$ expression in entorhinal cortex correspond to a band of $\operatorname{Kv} \beta 1$ immunoreactivity in the molecular layer of the dentate gyrus (data not shown). One clear exception to this relationship is that numerous cortical and hippocampal interneurons contain high levels of $\operatorname{Kv} \beta 1$ mRNA and also contain a high density of $\mathrm{Kv} \beta 1$ immunoreactivity at their somata and proximal dendrites.

Overall, the pattern of $\mathrm{Kv} \beta 1$ expression corresponds closely to that observed for Kv1.4 (Sheng et al., 1992) and, to a lesser extent, Kv1.1 (Wang et al., 1994). In agreement, the high levels of $\operatorname{Kv} \beta 1$ immunoreactivity in the globus pallidus and pars reticulata of the substantia nigra correspond closely to the patterns reported for Kv1.1 and Kv1.4 in these structures (Sheng et al., 1992; Wang et al., 1994). Similarly, the high levels of $\mathrm{Kv} \beta 1$ immunoreactivity in cortical interneurons corresponds closely to the patterns of expression and immunoreactivity for $\mathrm{Kv1.1,} \mathrm{Kv1.2,} \mathrm{and} \mathrm{Kv1.6} \alpha$ subunits in these cells (Wang et al., 1994) (M. Monaghan, N. Barrezueta, J. Trimmer, K. Rhodes, unpublished observations). This observation suggests that $\mathrm{Kv1.1}, \mathrm{Kv} 1.2, \mathrm{Kv} 1.6, \mathrm{Kv} \beta 1$, and perhaps $\mathrm{Kv} \beta 2$ may co-localize and co-assemble in these cells. In view of the high spontaneous firing rates and short-duration action potentials reported for cortical (hippocampal) interneurons (Williams et al., 1994), it is tempting to speculate that the high levels of $\mathrm{Kv} \beta 1$ expression and its subsequent effects on associated $\alpha$ subunits (Rettig et al., 1994) in these cells are related to an intrinsic requirement for rapidly inactivating channels.

Although Rettig et al. (1994) did not examine Kv $\beta 2$ expression in their study, the data reported here indicate that $\operatorname{Kv} \beta 2$ also is widely expressed in rat brain. Cohen and his colleagues (Arai et al., 1992; Cohen et al., 1992) have characterized the expression of a gene, F5 (Sabath et al., 1990), that is highly expressed in activated $\mathrm{T}$ lymphocytes and brain. The recent submission of the F5 sequence to the Genbank database identified F5 as the mouse homolog of $\mathrm{Kv} \beta 2$. The pattern of F5 mRNA expression in brain (Arai et al., 1992; Cohen et al., 1992) is qualitatively similar to that reported here for $\mathrm{Kv} \beta 2$, but is described more accurately as a composite of $\operatorname{Kv} \beta 1$ and $\operatorname{Kv} \beta 2$ mRNA expression. This may be attributable to the probe that was used for hybridization, which was derived from a region, which in rat, is highly conserved between $\operatorname{Kv} \beta 1$ and $\operatorname{Kv} \beta 2$ ( $80 \%$ identity at the nucleotide level).

Immunoreactivity for $\mathrm{Kv} \beta 2$ is concentrated in the juxtaparanodal regions of myelinated axons and in terminal fields of cells expressing $\operatorname{Kv} \beta 2$ mRNA. This is clearly evident in the cerebellar cortex, where $\operatorname{Kv} \beta 2$ mRNA is expressed in basket cells and $\mathrm{Kv} \beta 2$ immunoreactivity concentrated in the basket-cell terminal plexus, and in the hippocampus, where $\mathrm{Kv} \beta 2$ mRNA is expressed in layer II cells in entorhinal cortex and $\mathrm{Kv} \beta 2$ immunoreactivity is present in the molecular layer of the dentate gyrus. However, there also are clear examples of $\mathrm{Kv} \beta 2$ immunoreactivity in somatic and dendritic domains. For example, in cortical and hippocampal pyramidal cells, $\mathrm{Kv} \beta 2$ immunoreactivity is concentrated in the cell body and throughout the apical dendritic tree, and in cerebellar Purkinje cells, $\mathrm{Kv} \beta 2$ immunoreactivity is concentrated in somatic and dendritic domains.

In general, the pattern of expression and immunoreactivity for $\mathrm{Kv} \beta 2$ is best approximated by a composite of that reported for the Kv1.1 and Kv1.2 $\alpha$ subunits (Sheng et al., 1994; Wang et al., 1994; Rhodes et al., 1995). In cerebellar basket-cell terminals, the pattern of $\operatorname{Kv} \beta 2$ immunoreactivity corresponds precisely to that ob- 
served for Kv1.1 and Kv1.2 (McNamara et al., 1993; Wang et al., 1993, 1994; Sheng et al., 1994; Rhodes et al., 1995; Shi et al., 1996), indicating that $\mathrm{Kv} \beta 2$ is likely to be associated with Kv1.1 and Kv1.2 in these complexes. Similarly, in the juxtaparanodal membrane of myelinated axons, the pattern of $\mathrm{Kv} \beta 2$ immunoreactivity is identical to that observed for Kv1.1 and Kv1.2 (Wang et al., 1993, 1994; Sheng et al., 1994; Shi et al., 1996). In other regions, such as the somatodendritic membranes of cortical pyramidal cells and the cell bodies of midbrain and brainstem motor neurons, the pattern of $\mathrm{Kv} \beta 2$ immunoreactivity also corresponds closely to Kv1.1 and Kv1.2. However, in other regions, such as the apical dendritic trees of cortical and hippocampal pyramidal cells, the pattern of $\mathrm{Kv} \beta 2$ immunoreactivity is matched by that for Kv1.6 (K. Rhodes, M. Monaghan, J. Trimmer, unpublished observations) and Kv4.2 (Sheng et al., 1992), but not by any of the other $\operatorname{Kv} 1$ family $\alpha$ subunits. Because $\operatorname{Kv} \beta 2$ (and $\operatorname{Kv} \beta 1$ ) can associate with all $\mathrm{Kv} 1 \alpha$ subunits, as well as Kv4.2, in heterologous expression systems (Nakahira et al., 1996), in pyramidal cell dendrites, $\mathrm{Kv} \beta 2$ may be present in channel complexes containing Kv1.6 or Kv4.2. However, this association remains to be confirmed by reciprocal co-immunoprecipitation studies.

The results of the present study indicate that $\beta$ subunits are fundamental components of voltage-gated $\mathrm{K}^{+}$channels in mammalian brain. Their widespread expression and tight association with $\alpha$ subunits suggests that they play a fundamental role in the function of native channels (Parcej and Dolly, 1989, 1992; Trimmer, 1991; Scott et al., 1994a,b; Rhodes et al., 1995; Shi et al., 1996). As both $\operatorname{Kv} \beta 1$ and $\operatorname{Kv} \beta 2$ are found in both presynaptic (axons and terminals) and postsynaptic (soma and dendrites) plasma membrane domains, it may be assumed that they in themselves do not effectively target $\mathrm{K}^{+}$channels to specific subcellular compartments (Sheng et al., 1992, 1994). Some $\beta$ subunits, including $\operatorname{Kv} \beta 1$, do exert dramatic effects on the electrophysiological properties of expressed channels (Rettig et al., 1994; England et al., 1995a,b; Majumder et al., 1995; Morales et al., 1995). However, $\operatorname{Kv} \beta 2$, the major $\beta$ subunit in brain, does not, raising questions as to its precise function. We reported recently that $\operatorname{Kv} \beta 2$ exerts chaperone-like effects on the Kv1.2 $\alpha$ subunit, promoting its efficient glycosylation, surface expression, and stability in the plasma membrane (Shi et al., 1996). Similar effects are mediated by $\operatorname{Kv} \beta 1$ (Shi et al., 1996). Interestingly, mutations in a Drosophila $\beta$ subunit result in a reduction in the surface density of $\mathrm{K}^{+}$channel complexes (Chouinard et al., 1995), supporting the contention that the effects of $\beta$ subunits on the biosynthetic maturation and stability of $\alpha$ subunits is a fundamental role. Further definition of the sites where $\beta$ subunits co-localize and co-associate with individual $\alpha$ subunits will further define the role of $\mathrm{Kv} \beta 1$ and $\mathrm{Kv} \beta 2$ in determining the properties of $\mathrm{K}^{+}$channel complexes in mammalian brain.

\section{REFERENCES}

Arai M, Prystowsky MB, Cohen JA (1992) Expression of the T-lymphocyte activation gene, F5, by mature neurons. J Neurosci Res 33:527-537.

Chouinard SW, Wilson GF, Schliomgen AK, Ganetsky B (1995) A potassium channel $\beta$ subunit related to the aldo-keto reductase superfamily is encoded by the Drosophila hyperkinetic locus. Proc Natl Acad Sci USA 92:6763-6767.

Cohen JA, Arai M, Luning Prak E, Brooks SA, Young LH, Prystowsky MB (1992) Characterization of a novel mRNA expressed by neurons in mature brain. J Neurosci Res 31:273-284.

England SK, Uebele VN, Kodali J, Bennett PB, Tamkun MM (1995a) A novel $\mathrm{K}^{+}$channel $\beta$-subunit $(\mathrm{hKv} \beta 1.3)$ is produced via alternative mRNA splicing. J Biol Chem 270:28531-28534.
England SK, Uebele VN, Shear H, Kodali J, Bennett PB, Tamkun MM (1995b) Characterization of a voltage-gated $\mathrm{K}^{+}$channel $\beta$ subunit expressed in human heart. Proc Natl Acad Sci USA 92:6309-6313.

Harlow E, Lane D (1988) Antibodies: a laboratory manual. Cold Spring Harbor, NY: Cold Spring Harbor Laboratory.

Heinemann SH, Rettig J, Wunder F, Pongs O (1995) Molecular and functional characterization of a rat brain $\operatorname{Kv} \beta 3$ potassium channel subunit. FEBS Lett 377:383-389.

Hille B (1992) Ionic channels of excitable membranes. Sunderland, MA: Sinauer.

Isom LL, De Jongh KS, Catterall WA (1994) Auxiliary subunits of voltage-gated ion channels. Neuron 12:1183-1194.

Jan LY, Jan YN (1990) How might the diversity of potassium channels be generated? Trends Neurosci 13:415-419.

Johnson DAG, Sportsman JR, Elder JH (1984) Improved technique utilizing nonfat dry milk for analysis of proteins and nucleic acids transferred to nitrocellulose. Gene Anal Tech 1:3-8.

Maizel JV (1971) Polyacrylamide gel electrophoresis of viral proteins. Methods Virol 5:179-246.

Majumder K, De Biasi M, Wang Z, Wible BA (1995) Molecular cloning and functional expression of a novel potassium channel $\beta$-subunit from human atrium. FEBS Lett 361:13-16.

McCormack K, McCormack T, Tanouye M, Rudy B, Stühmer W (1995) Alternative splicing of the human Shaker $\mathrm{K}^{+}$channel $\beta 1$ gene and functional expression of a $\beta 2$ gene product. FEBS Lett 370:32-36.

McNamara NM, Muniz ZM, Wilkin GP, Dolly JO (1993) Prominent location of a $\mathrm{K}^{+}$channel containing the alpha subunit Kv1.2 in the basket cell nerve terminals of rat cerebellum. Neuroscience 57:1039-1045.

Mesulam M-M, Mufson EJ, Wainer BH, Levey AI (1983) Central cholinergic pathways in the rat: an overview based on an alternative nomenclature (Ch1-Ch6). Neuroscience 10:1185-1201.

Morales MJ, Castellino RC, Crews AL, Rasmussen RL, Strauss HC (1995) A novel $\beta$ subunit increases the rate of inactivation of specific voltage-gated potassium channel $\alpha$ subunits. J Biol Chem 270:6272-6277.

Nakahira K, Shi G, Rhodes KJ, Trimmer JS (1996) Selective interaction of voltage-gated $\mathrm{K}^{+}$channel $\beta$-subunits with $\alpha$-subunits. J Biol Chem 271:7084-7089.

Parcej DN, Dolly JO (1989) Elegance persists in the purification of $\mathrm{K}^{+}$ channels. Biochem J 264:623-624.

Parcej DN, Scott VES, Dolly JO (1992) Oligomeric properties of $\alpha$-dendrotoxin-sensitive potassium channels purified from bovine brain. Biochemistry 31:11084-11088.

Pongs O (1992) Molecular biology of voltage-dependent potassium channels. Physiol Rev 72 [Suppl 4]:S69-S88.

Pongs O (1995) Regulation of the activity of voltage-gated potassium channels by $\beta$ subunits. Semin Neurosci 7:137-146.

Rettig J, Heinemann SH, Wunder F, Lorra C, Parcej DN, Dolly JO, Pongs $\mathrm{O}$ (1994) Inactivation properties of voltage-gated $\mathrm{K}^{+}$channels altered by presence of $\beta$-subunit. Nature 369:289-294.

Rhodes KJ, Keilbaugh SA, Barrezueta NX, Lopez KL, Trimmer JS (1995) Association and colocalization of $\mathrm{K}^{+}$channel $\alpha$ - and $\beta$-subunit polypeptides in rat brain. J Neurosci 15:5630-5671.

Ruppersberg JP, Schroter KH, Sakmann B, Stocker M, Sewing S, Pongs O (1990) Heteromultimeric channels formed by rat brain potassiumchannel protein. Nature 345:535-537.

Sabath DE, Podolin PL, Comber PG, Prystowsky MB (1990) cDNA cloning and characterization of interleukin 2-induced genes in a cloned T helper lymphocyte. J Biol Chem 265:12671-12678.

Scott VE, Muniz ZM, Sewing S, Lichtinghagen R, Parcej DN, Pongs O, Dolly JO (1994a) Antibodies specific for distinct Kv subunits unveil a hetero-oligomeric basis for subtypes of $\alpha$-dendrotoxin-sensitive $\mathrm{K}^{+}$ channels in bovine brain. Biochemistry 33:1617-1623.

Scott VE, Rettig J, Parcej DN, Keen JN, Findlay JB, Pongs O, Dolly JO (1994b) Primary structure of a $\beta$-subunit of $\alpha$-dendrotoxin-sensitive $\mathrm{K}^{+}$channels from bovine brain. Proc Natl Acad Sci USA 91:1637-1641.

Sheng M, Tsaur ML, Jan YN, Jan LY (1992) Subcellular segregation of two A-type $\mathrm{K}^{+}$channel proteins in rat central neurons. Neuron 9:271-284.

Sheng M, Liao YJ, Jan YN, Jan LY (1993) Presynaptic A-current based on heteromultimeric $\mathrm{K}^{+}$channels detected in vivo. Nature 365:72-75.

Sheng M, Tsaur ML, Jan YN, Jan LY (1994) Contrasting subcellular localization of the Kv1.2 $\mathrm{K}^{+}$channel subunits in different neurons of rat brain. J Neurosci 14:2408-2417. 
Shi G, Kleinklaus A, Marrion N, Trimmer JS (1994) Properties of Kv2.1 $\mathrm{K}^{+}$channels expressed in transfected mammalian cells. J Biol Chem 269:23204-23211.

Shi G, Nakahira K, Hammond S, Rhodes KJ, Schechter LE, Trimmer JS (1996) $\beta$-subunits promote $\mathrm{K}^{+}$channel surface expression through effects early in biosynthesis. Neuron 16:843-852.

Stühmer W, Ruppersberg JP, Schroter KH, Sakmann B, Stocker M, Giese KP, Perschke A, Baumann A, Pongs O (1989) Molecular basis of functional diversity of voltage gated potassium channels in mammalian brain. EMBO J 8:3235-3244.

Trimmer JS (1991) Immunological identification and characterization of a delayed rectifier $\mathrm{K}^{+}$channel in rat brain. Proc Natl Acad Sci USA 88:10764-10768.

Trimmer JS, Trowbridge IS, Vacquier VD (1985) Monoclonal antibody to a membrane glycoprotein inhibits the acrosome reaction and associated $\mathrm{Ca}^{2+}$ and $\mathrm{H}^{+}$fluxes of sea urgin sperm. Cell 40:697-703.

Wang H, Kunkel DD, Martin TM, Schwartzkroin PA, Tempel BL (1993) Heteromultimeric $\mathrm{K}^{+}$channels in terminal and juxtaparanodal regions of neurons. Nature 365:75-79.

Wang H, Kunkel DD, Martin TM, Schwartzkroin PA, Tempel BL (1994) Localization of Kv1.1 and Kv1.2, two K channel proteins, to synaptic terminals, somata, and dendrites in the mouse brain. J Neurosci 14:4588-4599.

Williams S, Samulack DD, Beaulieu C, LaCaille JC (1994) Membrane properties and synaptic responses of interneurons located near the stratum lacunosum-moleculare/radiatum border of area CA1 in whole-cell recordings from rat hippocampal slices. J Neurophysiol 71:2217-2235. 